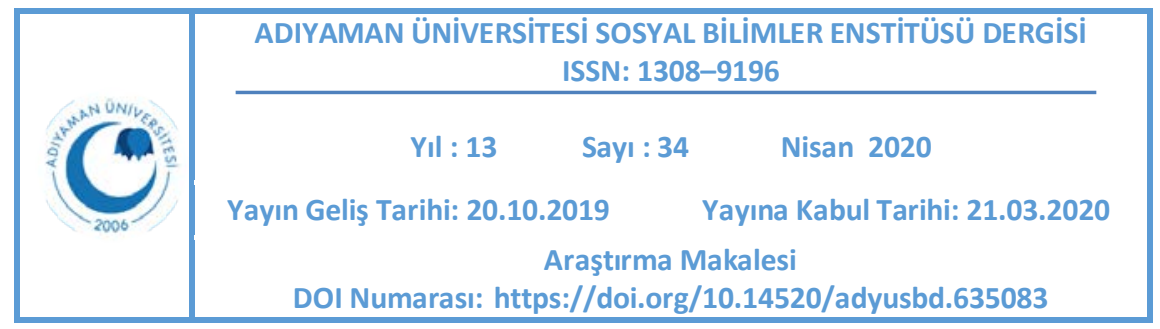

\title{
ESKI TÜRKÇEDE KOKU, TÜTSÜ VE BUHURDAN*
}

\section{Uğur UZUNKAYA**}

\begin{abstract}
$\ddot{O} z$
II. Doğu Türk Kağanlığı (632-744), Uygur Bozkır Kağanlığı (744-840) ve Koço Uygur Hanlığı (860-1284) dönemlerine ait Eski Türkçe yazıtlar ve yazmalar ile Yenisey, Dağlık Altay Bölgesi ve Kırgızistan'da bulunan yazıtlar bugün Eski Türkçenin söz varlığının doyurucu bir malzemesini sunar. Bu döneme ilişkin metinler dinî, sosyal, kültürel ve askerî terimler başta olmak üzere muhtelif alanlara ilişkin birçok terimi ihtiva eder. Bu çalışmanın amacını Eski Türkçe metinlerde geçen kokuya ilişkin ifadeler ile tütsü ve buhurdan anlamındaki sözcüklerin tespiti ve kökenlerine ilişkin açıklamalar oluşturmaktadır. Çalışmada Orhon Türkçesi ile kaleme alınmış yazıt ve yazmalarla Eski Uygurca metinlerde geçen mevzubahis sözcükler madde başı olarak alınmıştır; bununla birlikte tarihî Türkçenin diğer dönemlerine ilişkin metinlere de atıf yapılarak madde başı olarak belirlenen sözlerin özellikle orijinal metinlerdeki ve Türk diline ilişkin iki dilli sözlüklerdeki görünümlerine yer verilmiştir. Bu çalışmadaki malzeme Eski Türkçede Kokuya ilişkin ifadeler ile Eski Türkçede Tütsü ve Buhurdan olmak üzere iki ayrı başlıkta incelenmiştir.
\end{abstract}

Anahtar Kelimeler: Eski Türkçe, terim, koku, tütsü, buhurdan.

\footnotetext{
* Bu çalışma 11.10.2019 tarihinde Çin Halk Cumhuriyeti'nin Hohhot şehrinde düzenlenen Analyses of Languages and Literature of the Prairie Silk Road and the History of the Northern Ethnic Groups (I) Reanalysis of Old Turkic and Uighur Documents isimli uluslararası çalıştayda sözlü olarak sunulmuş bildirinin yeniden gözden geçirilerek ve eklemeler yapılarak hazırlanmış biçimidir.
}

Dr. Öğr. Üyesi, Erzurum Teknik Üniversitesi, Edebiyat Fakültesi, Türk Dili ve Edebiyatı Bölümü, uguruzunkaya1@gmail.com, Erzurum/Türkiye. 


\title{
SMELL, INCENSE AND CENSER IN OLD TURKIC
}

\begin{abstract}
Inscriptions and manuscripts belonging to the periods of the Second Turkic Khanate (632-744), the Uighur Khanate (744-840) and the Uighur Kingdom of Kocho (860-1284), and the inscriptions found in Yenisei, Mountainous Altai and Kyrgyzstan present a satisfying vocabulary of Old Turkic. The texts of this period contain many terms related to diverse fields, especially religious, social, cultural and military terms. The aim of the paper is to determinate the words in the meanings of smell, incense and censer in Old Turkic texts and to explain these words etymologically. In this study, the words in question determinated in the inscriptions and manuscripts in Orkhon Turkic and Old Uighur are taken as lexical entry; in addition, the texts of other periods of historical Turkish are cited for these lexical entries and their forms in the original texts and bilingual dictionaries of Turkic languages are also demonstrated.
\end{abstract}

Keywords: Old Turkic, Terms, Smell, Incense, Censer.

\section{GiRiş}

Türk dilinin tarihsel gelişimi göz önünde bulundurulduğunda, II. Doğu Türk Kağanlığı (632-744), Uygur Bozkır Kağanlığı (744-840) ve Koço Uygur Hanlığı (860-1284) dönemlerine ait yazıtlar ve yazmalar ile klasik dışı yahut da kağanlık dışı olarak da bilinen Yenisey, Dağlık Altay Bölgesi ve Kırgızistan'da bulunan yazıtlar, kaya yazıtları ve kâğıda yazılı belgeler Eski Türkçenin temel yazılı kaynaklarını oluşturmaktadır. Bazı araştırmacılar Karahanlı Türkçesiyle kaleme alınmış ilk dönem metinlerini de Eski Türkçe içinde saysa da Eski Türkçenin biri Orhon Türkçesi ve biri de Eski Uygurca olmak üzere bilinen iki diyalekti bulunmaktadır. Eski Türkçe, muhtelif dinî muhitlerin ve dillerin etkisinde şekillenen bu literatürle kabaca 8. yüzyıldan 13. yüzyıla kadarki süre zarfında yazılı kaynaklar aracılığıyla tanıklanabilmektedir. Türkçenin tarihî dönemlerinin tamamında olduğu gibi Eski Türkçe dönemine ait yazıtlar ve yazma eserler de 
çok çeşitli alanlara ilişkin terimleri intiva eder. ${ }^{1}$ Bunlardan biri de kokuyu adlandırmada kullanılan kavramlar ile bununla ilişkili olarak tütsü ve buhurdan kavramlarıdır. Hemen bütün Türk dillerinde kokuya ilişkin ifadeler ve bu ifadelerin anlamlandırımasına ilişkin meselelerin mukayeseli olarak fonetik ve semantik düzlemde tespiti ve incelemesi başlı başına bir çalışma konusunu oluşturabilecek düzeydedir.

Kokuya ait ifadeler bütün dillerde kokunun niteliğine ilişkin özel bilgiyi de barındırır. Bununla ilişkili olarak değerlendirilebilecek meselelerden biri ise tütsüdür. Tarih boyunca çeşitli kültür ve medeniyet daireleri içerisinde tıbbî, dinî, törensel ve onursal maksatlarla kullanımı yazılı kaynaklar aracılığıyla tanıklanabilen tütsü ve tütsü yakma geleneği, semavî olsun olmasın hemen her dinî alanda ve bununla birlikte din dışı alanda oldukça önemli bir yere sahiptir. Egzotik bir maddeyi ve hoş bir kokuyu ihtiva eden çeşitli bitkilerin usaresi ve reçinesinden yahut da doğrudan bitkinin kendisinden veya kabuğundan hazırlanan, ısıtılması yahut yanmasıyla tesir gösteren tütsüler, kokunun etki alanını oluşturan her sahada gerçekleştirilen işlemin geçerliliğinin sağlanmasında ve artırılmasında güçlü bir aracı görev üstlenmişlerdir. Birbirinden farklı dinî inanışa, coğrafyaya, dile ve tarihsel seyre sahip olunsa da Hindistan, Mısır, Arabistan, Mezopotamya gibi kültürel çevrelerde tütsü kullanımı mevcut olmuş, bununla beraber malzemesi ve tesir alanı her defasında farklılaşmış olsa da ona atfedilen önem tarihin her döneminde canlı kalabilmiştir.

Bu çalışmanın amacı yaygın bir kültür çevresinde kendisine yer edinmiş olan koku, tütsü ve buhurdan kavramlarını Türk dilinin en eski yazılı kaynakları olarak kabul edilen Eski Türkçe dönemi dil yadigârları üzerinden incelemektir.

\footnotetext{
${ }^{1}$ Bu çalışma esasen Türkçenin tarihî dönemlerinin tamamını içerebilirdi; ancak böylesi bir çalışma bir makale boyutunu ziyadesiyle aşacağı için yalnızca Eski Türkçe dönemiyle sınırlandırıldı.
} 
Çalışmanın özellikle Eski Türkçe üzerine odaklanmasının sebebi bu dönemin Türkçe ve başka komşu dillerden çok çeşitli söz varlığını ihtiva etmesi ve ayrıca bu söz varlığının Budizm, Manihaizm, Hristiyanlık gibi birbirinden farklı dinî muhitlerden beslenmesidir. Çalışmanın örneklem alanını Orhon ve Uygur dönemi runik harfli yazıt ve metinler ile Eski Uygurca ile kaleme alınmış mezkur dinî muhitlere ilişkin eserler oluşturmaktadır. Bu çalışmaya Eski Türkçe metinlerde geçen kokuya ilişkin terimler ile tütsü ve buhurdan anlamındaki sözcükler madde başı olarak dahil edilmiştir. Bir yöntem olarak madde başı olarak belirlenen bu malzemenin köken bilgisine ışık tutulmuş, kaynak dildeki karşılıklarına yer verilmiş ve bunların metin içindeki anlamlarına değinilmiştir.

Bu çalışma "Eski Türkçede Kokuya Iliş̧̧nin Ifadeler" ve "Eski Türkçede Tütsü ve Buhurdan" olmak üzere iki başııtan oluşmaktadır.

\section{ESKI TÜRKÇEDE KOKUYA ILIŞKIN IFADELER}

Runik harfli Türk yazıtlarında ve Eski Uygurca metinlerde kokuya ilişkin terimler arasında şu sözcükler ve ifadeler tespit edilmiş ve alfabetik olarak sıralanmıştır.

bur-: Sözcük 'kokmak, koku salmak' anlamındadır. Clauson bu fiilin bu 'buhar' anlamındaki sözcükten türediğini ve anlamının 'buhar çıkarmak, misk kokulu olmak' olduğunu belirterek Türkçenin modern ve tarihi dönemlerinden örnekler sunar (1972: 355a; ayrıca krş. Nadalyayev vd., 1969: 125a). OTWF'de bu+rşeklinde açıklanan sözcük 'buhara dönüşmek' dolayısıyla da 'buhar çıkarmak, hoş koku vermek' şeklinde anlamlandırılmıştır (Erdal, 1991: 500; ayrıca bū 'buğu' için krş. Tekin, 1995: 179). Sözcük HT X'da iki kez tanıklanmıştır: yänä önisig ädgü yıd yıparlar bura kötiyü turdı (Mirsultan, 2010: 104-105351-352) “Yine olağanüstü, mucizevi güzel kokular2 yükseldi." ve ol lenhua çäçäk yıdı [y]ıparı p(a)ryan içintä inçä ök [b]ura ködiyü yıdıyu turdı (Mirsultan, 2010: 133650-652) “Her lotus çiçeğinin güzel kokusu 2 güzel koktu ve ayrıca aynı biçimde rahip 
hücresinde de güzel koktu." Sözcük Ein uigurischer Neujahrssegen olarak adlandırılan din dışı bir Eski Uygurca metinde (Zieme, 1984: 343 55 ; ayrıca krş. Ayazlı, 2016: 93) ve Yüan dönemine ait bir Budist Uygur metninde de (Tekin, 1980b: 231 ${ }_{592}$ ) tanıklanmıştır. bur- fiili DLT'de 'yayılmak, yükselmek' anlamlarıyla mevcuttur ve Ar. fāḥat, taḍawwa'a ve irtafa'a yapılarıyla karşılanmıştır: yıpar burdı "Misk kokusu yayıldı (fāḥat)." ve suw burdı "Buhar (vb.) yükseldi (irtafa'a)." (Dankoff ve Kelly, 1982: 390, sh. 266). KB'de bu fiil dört yerde tanıklanmıştır 'kokmak, güzel kokmak' anlamlarındadır (Arat, 1979: 116). Fiil Kitābu'I-Idrāk li Lisāni'l-Etrāk'ta burı- 'misk kokmak' şeklinde geçmektedir ve Ar. fāḥa'l-misk karşılığında kullanılmıştır (Özyetgin, 2001: 418).

kapir: 'Tütsü' anlamındaki AYS VI'da geçen bu sözcük kökeni itibarıyla Skt. karpūra'ya dayanır (Ayazlı, 2012: 315b). Skt. karpūra 'kâfur (ya bitki ya reçineli Sızıntı veya meyve)' (Monier-Williams, 1899: 258b) anlamındadır. AYS VI'daki kapir karşılığında Çin. metinde 龍腦 long nao (Taishō No. 665, c. 16, 430c18; Hirakawa, 1997: 1305b; Ayazlı, 2012: 315b) 'ejderha beyni, tütsü’ (DDB) geçmektedir.

kin yıpar: Clauson kin sözcüğünü 'misk' olarak anlamlandırır ve kin yıpar tabiri için Manichaica II'ye atıfta bulunur (1972: 725a; ayrıca yıpar kin için krş. Nadalyayev vd., 1969: 267b). AYS VII'de m(a)haboga kin yıpar 'misk' (Çetin, 2012: $135_{398}$ ) ifadesi mevcuttur (Çetin, 2012: 240b). Bu ifadenin Çin. metindeki karşılığı 鹿香莫迦婆伽 shexiang mojiapoqie'dir (Taishō No. 665, c. 16, 435a01). Çetin, Çin. metne göre Uyg. metindeki kin yıpar sözünün daha önce kullanılması gerektiğini belirtir (2012: 201). kin yıpar ifadesinin Çin. metindeki karşılığı 鹿香 shexiang 'misk'tir (DDB). Çin. metindeki 莫迦婆伽 mojiapoqie ifadesi ise Skt. mahābhāga karşılığındadır; ancak Skt. biçimdeki anlam 'ünlü’dür (Monier- 
Williams, 1899: 798a; Edgerton, 1953: 424a). DLT'de kin yıpar ifadesinin karşılığı olarak Ar. nāfica misk 'misk kesesi' (sh. 171) bulunmaktadır (Dankoff ve Kelly, 1982: 268). KB'de kin yıpar tabiri 'misk göbeği' anlamında ikileme şekliyle iki yerde tespit edilmiştir (Taş, 2012: 60). kin yıpar tabirine kin yıparlar burar (vr. 239r8) 'miskler kokar' bağlamıyla Ḳıșașü'l-Enbiyā'da da rastlanır (Ata, 1997: 346; Boeschoten ve O’Kane, 2015: 531). kin sözcüğü yalnız başına Kitābu'l-idrāk li Lisāni'l-Etrāk'ta Ar. karşılığı ile el-misk 'misk kokusu' (Caferoğlu, 1931: 49 ve 85a) olarak geçmektedir.

kinlig: Sözcük 'misk kokulu' anlamındadır. T. Tekin, yazıtların ilk dönem neşirlerinde sözcüğün (e)kinl(i)g şeklinde okunduğunu ve buradaki (e)kin'in bilinen ekin sözcüğü sanıldığını ifade eder. Tekin bundan sonra gelen sözcüğün DLT'de geçen eşgürti ve Uyg. metinlerdeki eşgirti 'işlemeli ipek kumaş' olduğunu belirterek, esasen ekin sözcüğünün <i> olmadan $k^{2} n^{2}$ ile yazılması gerektiğini belirtir ve kinl(i)g (e)şgiti ifadesini 'misk kokulu işlemeli ipek kumaş' olarak anlamlandırır (1988: 98). Bu sözcüğün yapısı Clauson tarafından kin+lig 'misk kokulu' olarak açıklanır. Clauson sözcüğün kin yani 'misk' anlamındaki sözcükten türediğini belirtirerek hap[ax] leg[omenon] 'tek örnek' olarak kaydeder (1972: 732a). ${ }^{2}$ Sözcük BK K 11'de şu bağlamda geçmektedir:

[sarıg altu]nin : ürün : kümüşsin : "Çil çil altınları, apak gümüşleri, kenarlı k'ırgaglıg : kotayin : kinlig : eşg[itis]in: ipekleri, misk kokulu ipeklileri, has özlik atin : adgırin : kara k[işin] kök : atları, aygırları, kara samur ve boz teyenin : türüküme : bodunuma : sincap (derilerini) hakanlık halkım için,

\footnotetext{
2 kinlig sözüne Eski Uygurca metinlerde de rastlanır; ancak yukarıda geçen anlamdan farklıdır. Zieme'nin neşrettiği “Drei neue uigurische Sklavendokumente" de bu sözcük yüz iki uçı kinlig otra tamgalıg kunpoka üzüştümüz bağlamında geçer ve kinlig soru işaretiyle 'Lienenballen II keten balyası' olarak anlamlandırılmıştır (1977: 1555-6). Din dışı metinlerde geçen kinlig (< Çin. 巾 jin + Tü. +lig) 'şeritli, bağlı' (Ayazlı, 2016: 155) anlamındadır.
} 
kazganu : bértim : èti bértim (Ölmez, kavmim için, kazandım, elde ettim." 2013: $\left.131_{11-12}\right)$

(Ölmez, 2013: 14511-12)

Mezkur sözcük muhtelif neşirlerde mevcut bağlamıyla şöyle okunmuş ve anlamlandırılmıştır:

\section{Kaynak}

Thomsen, 1896 [2002: 198-199]

Orkun, 1936: 58

Tekin, 1968: 246

Tekin, 1988: 32-33

Berta, 2010: 137 ve 192

Ölmez, 2013: 131 ve 145

Şirin, 2016: 264-265

Aydın, 2017: 78

\section{Sözcüğün yazı}

\section{çevirimi}

äkinl'g 'si'g[tis]in

${ }^{e}$ kinl'ğg 's'ğ[tis]in

äkinlig äsg[itis]īn

kin(i)g (e)şg[(i)tis]in

kinliy èş ${ }^{0}$ itisin

kinlig eşg[itis]in kinlig (ä)şg[(i)tis]in

kinlig işgitisin

\section{Anlam}

'isigti (?) tohumlarını'

'darının ekimli olanını'

'kokulu ipeklilerini'

'misk kokulu işlemeli kumaşı'

'misk kokulu ipeklileri'

'kokulu'

'misk kokulu ipeklileri'

kisarlıg: Sözcük Skt. keśara ve Tü. +lıg ekinden oluşmaktadır. Skt. keśara 'polen, çiçek tozu' (Edgerton, 1953: 193a) anlamındadır. Sözcüğe Maitrisimit nom bitig'de [= BT IX, 157v6] rastlanır: vasava elig hannın yänä uluşta balıkta vayțure ärd(i)ni ulunlug v(a)žir kisarlıg t(ä)k yapargakl(ı)g ärd(i)nilig lenhua çäçäk b(ä)Igülüg boltı (Tekin, 1980a: 1334-8) “Yine Hükümdar Vāsava'nın ülkesinde lacivert taşı-mücevher saplı ve güzel kokan elmas gibi yapraklı (Skt. vajrakeśara) ve mücevherle süslenmiş lotus çiçeği görünür oldu."3

köti-: Sözcük 'güzel kokmak' anlamındadır. Clauson bu sözcüğün kötür- fiiliyle olan bağlantısına ilişkin düşüncenin ihtimal dahilinde olmadığını belirterek Xuanzang Biyografisi'nde geçen çahşapatlıg yıparları bura kötiyü turur örneğinden yola çıkarak sözcüğün köpürü yerine yanlış okunmuş olabileceğini

${ }^{3}$ kisar, Eski Uygurca din dışı metinlerde geçen kisar / kesar 'aslan' (Ayazlı, 2016: 149) sözünden farklıdır. 
ifade eder (1972: 702a). Sözcüğün yazı çevirimi OTWF'de kய̈ti- olarak yapılır ve mevcut tanıklardan hareketle anlamın 'güzel kokmak, güzel bir koku salmak' şeklinde olacağı belirtilir. Erdal, kẅti- (<köt+i-) fiilinin kökünün semantik bir bağ olmamasına karşın köt 'kıç, kalça' olabileceğini belirtir (1991: 483). köti'kokmak, koku salmak' fiili Eski Uygurca metinlerde çoğunlukla bur- köti-, yıdıköti- ve bur- köti- yıdı- şeklinde ikileme biçiminde geçmektedir; ancak kimi neşirlerde bu ifade 'yükselmek' olarak tercüme edilmiştir. HT V'te sözcüğe Clauson'un da vermiş olduğu ç(a)hşap(a)tıg yıparları bura kötiyü t[urmışı] antag

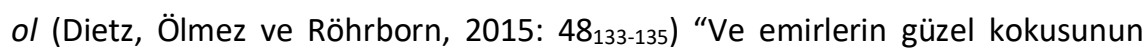
yükselmesi de aynıdır" örneğinde rastlanır ve burada Çin. metinde yıpar karşılığında 芬馥 fenfu 'mis kokulu, rayihalı' (Taishō No. 2053, c. 50, 246a23; DDB) ve bur- köti- karşıllı̆ında ise 香 xiang 'parfüm sürmek, parfümlemek' (Taishō No. 2053, c. 50, 246a23; DDB) bulunmaktadır. HT VII'de sözcük iki yerde tanıklanmıştır; ancak Röhrborn bur- ködi- ve yıdı-ködi- ifadelerini ikileme şeklinde değerlendirmemiştir. HT VII 690'daki bur- ködi- karşılığında Çin. metinde 薰 xun 'güzel kokmak, parfüm sürmek' (Taishō No. 2053, c. 50, 258c11; DDB) geçer: kızılı köki basışıp yaltrıyur tüşröki sarıgı bura ködiyü turur

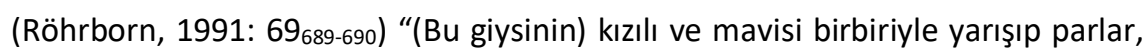
karışık renkli ve sarısı kokarak yukarıya çıkar." HT VII 1249'daki yıdı- ködikarşılığında Çin. metinde 香 xiang 'güzel koku saçmak' (Taishō No. 2053, c. 50, 260a02; DDB) sözcüğü geçer: kök tütsüg tütün yıdıy[u] ködiyü turgay kök kalıkta (Röhrborn, 1991: 112 1248-1249; ayrıca yıdı-ködi- için krş. Semet, 2005: 173) “Mavi tütsü dumanı güzel kokarak gökyüzünde 2 yukarı çıkmalı!" (Röhrborn, 1991: 113). HT IX'da sözcüğe bur- ködi- 'güzel kokmak' ikilemesiyle rastlanır ve Çin. metinde eş değeri olarak 'hoş kokulu, rayihalı' anlamında 芬芳 fen fang (Taishō No. 2053, c. 50, 268b21) bulunmaktadır: burar ködiyür "güzel kokar2," (Aydemir, 2013: $86_{352}$ ). HT X'da sözcük iki yerde tanıklanmıştır: yänä önisig ädgü yıd 
yıparlar bura kötiyü turdı (Mirsultan, 2010: 104-105351-352) "Yine olağanüstü, mucizevi güzel kokular 2 yükseldi." Bu kısımda yıd yıpar karşılığında Çin. metinde 香氣 xiang qi (Taishō No. 2053, c. 50, 276b17) 'güzel ve hoş koku' ifadesi geçmektedir. Eski Uygurca Abitaki metinlerinde sözcüğe üç yerde rastlanır. Bunlardan ilki bur- köți- yıdı- tabiridir: ol y(a)ruk yaltrık içintä ... ... bura köțiyü

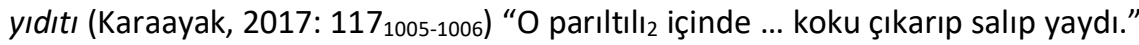
(Karaayak 2017: 239). Bunların dışında sözcük bur- köți- şeklinde geçer: ol oronta yıgılmış te[rilmiş] ... ... taplançıg yıdtınlar bura köțiyü ... (Karaayak, 2017: 126 1106-1107) "O makamda toplanmış birikmiş ... ... şaşırtıcı kokulardan salıp çıkarıp" (Karaayak, 2017: 245) ve ol [y(a)ruklug] y(a)ruk üzä yaltr(ı)yu yaşuyu önisi[g] ädgü [yıd]lar bura köțiyü turmışın "O parıltılı ışık ile parlayarak olağanüstü güzel kokular çıkarıp yayıp durduğunu" (Karaayak, 2017: 24911771179). AYS V 0068'de ve AYS IX 122'de geçen köti- sözcüğü ise sırasıyla 'yükselmek' (Uçar, 2009: 402, 68. not) ve '(koku) yükselmek' (Uçar, 2013: 272) olarak anlamlandırılmıştır.

sagbıç: Sözcük kökeni itibarıyla Skt. śallakī ile ilişkilendirilir (Çetin, 2012: 253a). Skt. śallakī 'tütsü, buhur' (Monier-Williams, 1899: 1059b) anlamındadır. Sözcük AYS VI 882'de geçer ve 'bir tür sıvı koku' olarak anlamlandırılır. AYS VI'daki ifadenin Çin. metindeki karşılığı 蘇合 su he 'tütsü'dür (Ayazlı, 2012: 131 1882 ). Sözcük AYS VII şaruki sagbıç (Çetin, 2012: 136410) şeklinde geçer ve Çin. metindeki karşılığı 吨脂 chi zhi'dir (Taishō No. 665, c. 16, 435a06; ayrıca bk. Çetin, 2012: 204).

sası-: Sözcük 'pis kokulu olmak, kötü kokmak' anlamındadır (Clauson, 1972: 855b). Erdal, OTWF'de şayet Codex Cumanicus'taki sas 'buğu, buhar' sözcüğü doğru ve eskiyse, sası- fiilinin yapısının sastı- şeklinde olabileceğini belirtir (1991: 784; ayrıca Nadalyayev vd., 1969: 490a; sāsı- biçimi için bk. Tekin, 1995: 
174). Sözcük Eski Uygurca metinlerden BT IX'da üç yerde geçer. Bunlardan bir örnek vermek gerekirse: tamulardın kurtulup bo pratikanarak kiçig tamularda tugmış ärür biz munta tugup tirig ärkän yıdıyu sasıyu yorıyur biz (Tekin, 1980a: 17515-19) “Cehennemlerden kurtulup bu küçük pratyekanaraka-cehennemlerde doğmuşuzdur. Burada doğup canlı iken kötü kokarak çürürüz." Bu ifade BT XXXVII'de yıdı- sası- ikilemesiyle geçmektedir: anı içintä beş akıgları olup äpräp kovuk suvuk arıgsızları birgärü katılıp açıyu çıvşayu yıd[ım]ış sasımış boksıg yıdıg kan[ları] yi[ri]りläri iç içägüläri bura bürkirä [yıdıyu] s[ası]yu ünä kältilär (Wilkens, 2016: $218_{304-309)}$ "Onun içinde beş vücut akıntıları ayrışıp 2 , yoğun ve ince akıntılı

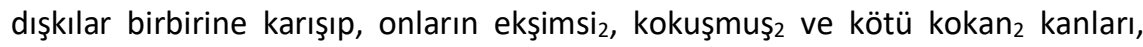
onların irinleri, iç organları duman çıkararak ${ }_{2}$ ve kötü koku yayarak 2 dışarı çıktılar." DLT'de sası- 'kötü kokmak' fiili karşılığında Ar. natuna mevcuttur: sasıdı nän "Bir şey çürüdü." (Dankoff ve Kelly, 1984: 287, sh. 561). Bu fiil Ḳıșașü'lEnbiyā'da yedi yerde 'kokmak, bozulmak' anlamıyla tanıklanmıştır: (...) aş kéçe ḳalsa sasımas erdi “(...) aş gece kalsa kokmazdı.” (vr. 119r1) (Ata, 1997: 166; Boeschoten ve O'Kane, 2015: 250). Nechü'l-Ferādis'te de sözcüğe üç yerde 'kötü, pis kokmak' anlamıyla rastlanır (Ata, 1998: 361b). Fiil Mukaddimetü'l$E d e b$ 'de sasıdı et yıd llandı ifadesinde yine 'kokuşmak, bozulmak' anlamıyla geçer (Yüce, 1993: 3734/7) Et-Tuhfetü'z-Zekiyye fi'l-Lugati't-Türkiyye sası- 'kötü kokmak' karşılığında Ar. natana, arwaha bulunur (Khairullah, 2015: 519, vr. 37a12).

sasıg: Sözcük sası- 'kötü kokmak' fiilinden -g ekiyle isim yapılmıştır ve 'pis kokulu, kötü kokulu' anlamındadır (Clauson, 1972: 856a). OTWF'de sözcüğün yapısı yine aynı şekilde açıklanarak bu ifadenin Eski Uygurca metinlerde yıdıg sasıg şeklinde göründüğü belirtilir (Erdal, 1991: 201). Erdal’ın (1991: 784) sasıfiili görüşü temelinde sözcüğün yapısı sas+ı-g olarak açıklanabilir. BT IX'da sözcük yıdıg sasıg ikilemesiyle birlikte geçer: ätözlärintä yıdıg sasıg yıd ünär (Tekin, 1980a: 248 198v20) “Bedenlerinde kötü koku yükselir." BT XXXVII'de 
sözcüğe yine yıdıg sasıg ikilemesiyle rastlanır: içi içägüsi täşilmäkinä bütün bagırıntın agızıntın [barça] yıdıg sasıg yavız yıd ünär (Wilkens, 2016: 5065377-5380) "iç̧ organları akıp gitmesi(yle) bütün karnından ağızından bütün pis kokulu kötü koku yükselir." DLT'de sasıg sözcüğünün barıg 'kokan şey (Ar. muntin)' birlikte sasıg barıg şeklinde kullanıldığı belirtilir (Dankoff ve Kelly, 1982: 286, sh. 186). sasıg sözcüğü Kitābu'l-idrāk li Lisāni'l-Etrāk'ta sası 'fena koku, müteafin' olarak geçer ve karşılığında Ar. șınatu'l-bevl 'idrar kokusu' bulunur (Caferoğlu, 1931: 88 ve $58 a)$.

şaruki: Sözcük, kökeni itibarıyla Skt. śallakī ile ilişkilendirilir (Çetin, 2012: 257a). Skt. śallakī 'tütsü, buhur' (Monier-Williams, 1899: 1059b) anlamındadır. Sözcük AYS VII şaruki sagbıç (Çetin, 2012: $136_{410}$ ) ifadesiyle geçer ve Çin. metindeki karşılığı 吨脂 chi zhi'dir (Taishō No. 665, c. 16, 435a06; ayrıca bk. Çetin, 2012: 204).

tagar: AYS Vl'da geçen bu sözcük kökeni itibarıyla Skt. tagaraka'ya dayanmaktadır. Skt. tagaraka 'Tabernaemontana coronaria ve ondan hazırlanan hoş kokulu bir toz' (Monier-Williams, 1899: 432a; ayrıca krş. Soothill ve Hodous, 1937: 209a) anlamındadır. Sözcüğün Çin. metindeki karşılığı olarak 多掲羅 duoqiluo (Taishō No. 665, c. 16, 430c18; DDB; Ayazlı, 2012: 341a) geçmektedir.

tütit-: Sözcük, tüt- fiiline getirilen ettirgen çatı eki -(i)t- ile oluşmuştur. Clauson tüt- fiilini madde başı olarak tütä- fiiline gönderir ve 'duman sızmak veya buhar çıkarmak' olarak anlamlandırır (1972: 452a). Erdal, Clauson'un tütär ifadesini tütä-r şeklinde yanlış ayırdığını daha doğru ayrımın tüt-är şeklinde olması gerektiğini ve bu sebeple tütä- madde başının yanlış olduğunu belirtir (1991: 
758, 491. dipnot; ayrıca krş. Nadalyayev vd., 1969: 601a). ${ }^{4}$ Sözcüğe Eski Uygurca Abhidharmakośabhāșya metninde iki yerde (35v19 ve 35v26) rastlanır. Bu metinde tütit- fiili 'parfüm sürmek' olarak anlamlandırılarak Çin. eş değer metindeki karşılığının 熏 xun olduğu belirtilmiştir. (Shōgaito, 2014: 197). ${ }^{5}$ Bu fiil DLT'de tütät- (belki tütit- ?) okunacak şeklinde fetha ile harekelenmiştir: ōt tütün tütätti “ateş duman çıkardı." Bu ifadenin tercümesi ise Ar. olarak dahhana'd-duhānu şeklindedir (Dankoff ve Kelly, 1984: 113, sh. 415). Bu noktada tütät- fiili Ar. duhbुana 'buhardan geçirmek, buhar ile dezenfekte etmek; (yiyecekleri) tütsülemek, (sigara) içmek' (Mutçalı, 2012: 298a) karşılığında kullanılmıştır.

tütitil-: Sözcüğün yapısı tüt-it-il- şeklinde açıklanabilir. Sözcüğe Eski Uygurca Abhidharmakośabhāșya metninde bir yerde rastlanır. Bu metinde tütitil- fiilinin anlamı 'parfüm sürünmek' olarak verilmiş ve Çin. eş değer metindeki karşılığının 熏 xun olduğu belirtilmiştir (Shōgaito, 2014: 28835v28).

tütnä-: Sözcüğün yapısı tüt-ün+ä- 'tütmek' şeklinde açıklanabilir. OTWF'de sözcüğün hap[ax] leg[omenon] 'tek örnek' olduğu belirtilir (Erdal, 1991: 426). Sözcüğe UigTot. metninde rastlanmıştır: içțin sınar tüțün tüțäyür täg irü b(ä)lgülär bolur (Zieme ve Kara, 1978: 84262-263) “iç tarafta tütün tüter gibi belirtiler, vardır."

yıd: Sözcük 'güzel koku, rayiha, koku' anlamındadır (Clauson, 1972: 883a; yīd 'koku' biçimi için bk. Tekin, 1995: 104). HT IX'da geçen yıdı ädgü yem[iş]lik kapıg (Aydemir, 2013: 109595-596) "güzel kokulu bahçenin kapısı" ifadesinde Uyg. yıd

\footnotetext{
${ }^{4}$ Clauson DLT'deki tütät- biçimi dolayısıyla bu fiili madde başı olarak alır ve sözcüğü '(bir şeyi) tüttürmek, (bir çukurdan bir hayvanı) ortaya çıkarmak' şeklinde anlamlandırmıştır (1972: 452a; ayrıca krş. Nadalyayev vd., 1969: 601a).

5 Shōgaito, Abhidharmakośabhāșya'nın 2008 tarihli neşrinde sözcüğü tütät- olarak okumuştur (2008: $694 \mathrm{~b}_{\mathrm{H} 35 \mathrm{v} 19}$ ).
} 
karşılığında Çin. metinde芳 fang 'rayihalı, hoş kokulu' (Taishō No. 2053, c. 50, 269a16; DDB) tabiri bulunmaktadır. Sözcük BT XXXVII'de ädgü yıd yıpar (Wilkens, 2016: 856 ${ }_{11781}$ ) 'iyi koku2' şeklinde ikileme olarak geçmektedir. UigTot.'da sözcük birden çok yerde tanıklanmıştır: yıdka sinmiştä burun yıd tuymaz (Zieme ve Kara, 1978: 5839-40) "kokuya sindiğinde burun koku duymaz". BT XXV'te birçok yerde tanıklanan yıd sözü 'güzel koku; pis koku' olarak anlamlandırılmış (Wilkens, 2007: 444b) ve Çin. metindeki karşıı̆ı̆ı olarak 氣 qi 'yel, hava, rüzgar' bulunmaktadır. Bunlara örnek vermek gerekirse, yıd[ı]g sas[ıg yıdı ıra]k ünmäki üzä (Wilkens, 2007: 100758) 'kötü ve keskin kokusu uzaktan yükselmesiyle' ifadesinde geçen yıdıg sasıg yıdı tabirinin Çin. metindeki karşılığı olarak 臭氣 xiu qi (Taishō No. 1909, c. 45, 925b24) 'kötü kokan rüzgarı' mevcuttur. BT XXV'te geçen bir başka ifade ise şöyledir: yıdıg sasıg oronlug yıdın (Wilkens, 2007: 270 $20_{3636-3637)}$ ) 'kokuşmuş yerin kokusunu' ifadesinin Çin. metindeki karşılığı 臭處之氣 xiu chu zhi qi (Taishō No. 1909, c. 45, 964c11-12) 'kötü kokan yerin yeli'dir. Her iki örnekte de yıd sözünün karşılığı olarak 氣 qi 'yel, hava, rüzgar' geçmektedir. yıd sözü KB'de 'koku' anlamıyla çokça tanıklanmıştır (Arat, 1979: 537). DLT'de yıd sözü (Dankoff ve Kelly, 1984: 173, sh. 465) Ar. rīḥ ile karşılanmıştır. Yûsuf suresi, 94. ayetteki Ar. rīḥ sözü TiEM 73'te kayıtlı Karahanlı Türkçesiyle kaleme alınmış Kur'an tercümesinde yıd ile karşılanmıştır (Kök, 2004: 175). Bu sözcük Ḳıșașü'l-Enbiyā'da 'koku' anlamıyla çokça tanıklanmış olup bir yerde yı $\underline{d}$ yıd ve O’Kane, 2015: 124) tabiriyle figura etymologica yapısıyla geçer.

yıdı-: Clauson sözcüğün yapısını yıd+ı- şeklinde açıklar ve 'nahoş bir kokusu olmak, kötü kokmak' olarak anlamlandırır (1972: 886a). OWTF'de de sözcüğün yapısı aynı şekilde gösterilerek 'iyi veya kötü kokmak' olarak anlamlandırılmış ve Eski Uygurca metinlere atıf yapılmıştır (Erdal, 1991: 484). HT VII'de yıdı- ködi- 
ifadesinin Çin. metindeki karşılığı olarak 香 xiang 'güzel koku saçmak' (Taishō No. 2053, c. 50, 260a02; DDB) sözcüğü geçer: kök tütsüg tütün yıdıy[u] ködiyü turgay kök kalıkta (Röhrborn, 1991: 1121248-1249; ayrıca yıdı- ködi- için krş. Semet, 2005: 173) "Mavi tütsü dumanı güzel kokarak gökyüzünde 2 yukarı çıkmalı!" (Röhrborn, 1991: 113). Sözcük HT X'da şu bağlamda geçer: ol lenhua çäçäk yıdı [y]ıparı p(a)ryan içintä inçä ök [b]ura ködiyü yıdıyu turdı (Mirsultan, 2010: 133650-652) "Her lotus çiçeğinin güzel kokusu2 güzel koktu ve ayrıca aynı biçimde rahip hücresinde de güzel koktu." KB'de yıd̆ı- fiili 'kötü kokmak' anlamıyla üç yerde tespit edilmiştir (Arat, 1979: 537). DLT'de yıd $ı$ - fiili Ar. ahamma 'kokmak, bozulmak, kokuşmak' (Mutçalı, 2012: 286a), antana 'çürütmek' (Mutçalı, 2012: 890a) (Dankoff ve Kelly, 1984: 191, sh. 480) ve natina 'kokuşmak, çürümek' (Dankoff ve Kelly, 1984: 285, sh. 559) ile karşılanmıştır.

yıdıg: 'Koku, kötü koku' anlamındaki sözcüğün yapısını yıd+ı-g şeklinde açıklamak mümkündür. Clauson sözcüğü 'rayiha, (her zaman değil, ama genellikle nahoş) koku; kötü kokulu' olarak anlamlandırır (1972: 887b). OTWF'de sözcüğün iyi kokudan ziyade kötü kokuya işaret ettiği belirtilerek Eski Uygurca metinlerdeki tanıklara atıf yapılır (Erdal, 1991: 218). BT XXIII'te [ol] balıkta yıdıg

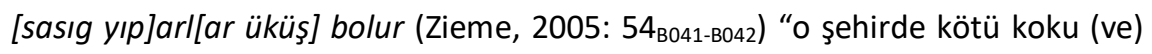
süprüntü çok olur" ifadesinde geçmektedir. BT XXV'te yıdıg sözü 'kötü kokan' olarak anlamlandırılmıştır (Wilkens, 2007: 444b). Bu metinde bir tamamlama olarak mevcut olan yıdıg sasıg (Wilkens, 2007: 2703641) 'kokuşmuş2' ifadesinin Çin. metindeki karşılığı 臭穢 xiuhui (Taishō No. 1909, c. 45, 964c16) 'kötü kokulu' anlamındadır. Yine bu metinde geçen yıd[ı]g sas[ıg yıdı ıra]k ünmäki üzä (Wilkens, 2007: 1000758) “kötü ve keskin kokusu uzaktan yükselmesiyle" ifadesinde geçen yıdıg sasıg tabirinin Çin. metindeki karşılığı olarak 臭 xiu (Taishō No. 1909, c. 45, 925b24) 'kötü kokan' ifadesi bulunmaktadır. yıdıg sözü sasıg ile birlikte ikileme olarak yine BT XXXVII'de de geçer: agızıntın [barça] yıdıg 
sasıg yavız yıd ünär (Wilkens, 2016: 5065379-5380) “ağzından bütün kötü berbat koku yükselir." KB'de yıdıg 'kötü kokulu (şey), kötü kokan (şey)' anlamıyla bir yerde tanıklanmıştır (Arat, 1979: 537; Taş, 2015: 127). DLT'de yıd̆ı̇ sözü Ar. muntin 'kötü kokan' (Mutçalı, 2012: 890b) (Dankoff ve Kelly, 1984: 152, sh. 449) ile karşılanmıştır. İbrâhim suresi, 50. ayette geçen Ar. ḳațrān sözü TiEM 73’te yıd̆ıg suv karşılığında geçer (Kök, 2004: 186). Yine Muhammed suresi, 15. ayette geçen Ar. āsin 'kokusu kötü' Karahanlıca Kur'an tercümelerinden Rylands nüshasında yıd̆gig ifadesiyle karşılanır (Ata, 2004: 37). Nechü'l-Ferādis'te de birçok yerde 'koku' anlamıyla rastlanır (Ata, 1998: 482a).

yıdışka-: Sözcüğün yapısına ilişkin OTWF'de yıdı-ş- fikri öne sürülür (Erdal, 1991: 464). S. Tezcan BT III'te geçen ıdışka- fiilinin yapısını ıd-ı-ş+ka- 'kokmak' şeklinde açıklar (Tezcan 1974: 38, 245. dipnot). Uçar, AYS V'teki notunda Tezcan'ın ve Ş. Tekin'in görüşlerine yer vererek ve Tezcan'a katılarak, sözcüğün yapısının yıdış+ka- şeklinde olması gerektiğini belirtir (2009: 468-469). AYS V'te geçen yıḍ yıparıg yıḍışkayur (Uçar, 2009: 192) "tütsüyü ${ }_{2}$ koklar" ifadesindeki yıdışkakarşılığında Çin. metinde 齅 xiu 'kokmak' (DDB) ifadesi mevcuttur (Uçar, 2009: $\left.468_{467-468}\right)$.

yıdıt-: Clauson sözcüğün yıdı- fiilinin ettirgen çatılı biçimi olduğunu belirterek 'kokutmak' anlamını verir (1972: 887a; ayrıca krş. Nadalyayev vd., 1969: 265a). OTWF'de yıdı-t- şeklinde açıklanan sözcüğün anlamı '(bir şeyi) kokutmak' olarak verilir (Erdal, 1991: 795). Runik harfli metinlerden Irk Bitig'in 59. falında yıdıt'kokutmak' fiiline rastlanır: yılka : tẹgmişig : yıdıtmạyın : ạka : tẹgmişig : ạrtatmạyın : ẹdgüsi : bolzun : tèr : ạnça : biliplẹr : ẹdgü : ol : (Yıldırım, 2017: 4759) “(Fal şöyle) der: 'Bir yıla değmişi kokutmayayım, bir aya değmişi bozmayayım. Hayırlısı olsun!' Öylece biliniz: (Bu fal) iyidir." (Yıldırım, 2017: 47). Bundan başka bu fiil BT XXXVII metninde yıdıt- sasıt- 'kokutmak2' olarak ikileme olarak geçer (Wilkens, 2016: 7569970). 
yıdla-: Sözcük 'koklamak' olarak anlamlandırmıştır (Clauson, 1972: 890b; Erdal, 1991: 451). Sözcüğün yapısını yıd+la- şeklinde açıklamak mümkündür. BT XXV'te

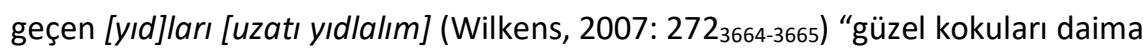
koklayalım” ifadesindeki yıdla- 'koklamak' fiilinin Çin. metindeki karşılı̆ı olarak 聞 wen (Taishō No. 1909, c. 45, 964c25) 'koklamak' geçmektedir. BT XXV'in Çin. metninde bu fiil düzenli olarak 聞 wen ile karşılanmıştır. BT XXXIII'te geçen yıdlayur (Oda, 2015: 158 ${ }_{169}$ ) ifadesinin karşılığı olarak Çin. metinde 齅 xiu 'koklamak' (Oda, 2015: 296 ${ }_{1283}$ ) geçmektedir. DLT'de yıd lla- fiili Ar. taşammama 'koklamak' ile karşılanmıştır (Dankoff ve Kelly, 1984: 307, sh. 579). Bununla birlikte DLT'de yıdllan- ve yıd̆laş- yapıları da mevcuttur. yıdllan- 'kokmak, kötü kokmak' fiili Ar. tarawwaḥa (Dankoff ve Kelly, 1984: 202, sh. 490) ve yıd̆laş'koklaşmak' fiili ise Ar. taşammamat (Dankoff ve Kelly, 1984: 198, sh. 487) ile karşılanmıştır.

yıdlıg: Sözcük 'kokulu, güzel kokulu' anlamındadır (Clauson, 1972: 890a). Sözcüğün yapısını yıd+lıg şeklinde açıklamak mümkündür. Eski Uygurca metinlerde bu sözcük sıkça yıdlıg yıparlıg ifadesiyle tanıklanır. BT XXIII'ten bir örnek verilebilir: yıdlıg yıparlıg suvın ädgü toprak katıp yogurup yerin suvamış kärgäk (Zieme, 2005: 69 D002-D004) "güzel kokulu suya iyi toprak katıp yoğurarak yerini sıvamalı." Sözcük Eski Uygurca metinlerin Çin. eş değerlerinde 香 xiang 'güzel koku' ifadesiyle geçmektedir. HT X'da geçen yıdlıg yıpar[lıg [aş]lar yemişlär (Mirsultan, 2010: 116 ${ }_{468-469}$ ) 'güzel kokulu 2 yemekler ve meyveler' ifadesi karşılığında Çin. metinde 香食美菓 xiangshi mei guo (Taishō No. 2053, c. 50, 276c20) 'kokulu yemek ve güzel meyve' geçmektedir. Yine aynı metinde bir

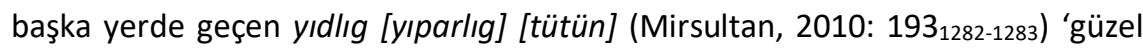
kokan duman' ifadesinin Çin. metindeki karşılığı olarak 香烟 xiang yan (Taishō 
No. 2053, c. 50, 279b18-19) 'güzel kokulu duman' ifadesi geçmektedir. Bunun

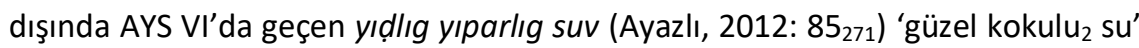
ifadesinin Çin. metindeki karşılığı olarak 香水 xiangshui (Taishō No. 665, c. 16, 428b12) 'güzel kokulu su' geçmektedir. MaueKat'ta geçen yitlig 'kokulu' (Maue, 1996: $46_{3.67}$ ) ise Skt. gandha 'koku, güzel kokulu' (Monier-Williams, 1899: 345a) karşılığıyla mevcuttur.

\section{ESKI TÜRKÇEDE TÜTSÜ VE BUHURDAN}

Runik harfli Türk yazıtlarında ve Eski Uygurca metinlerde tütsü ve buhurdan anlamında şu sözcükler tespit edilmiş ve alfabetik olarak sıralanmıştır.

käräşü: AYS VII'de geçen käräşü yürün küži (Çetin, 2012: 135) ifadesinin Çin. metindeki karşılığı 婆律膏掲羅娑 po lu gao jie luo suo'dur (Taishō No. 665, c. 16, 435a05). Çetin, 婆律膏 po lu gao'nun 'Dryobalanops aromatica' yani 'Borneo kâfuru' için kullanıldığını ve yürün küži'nin ise 'günlük' anlamında olduğunu belirtir (Çetin, 2012: 203).

kokılık: Sözcük 'tütsü' anlamındadır. T. Tekin A Grammar of Orkhon Turkic'de sözcüğün yapısını *qoq+lıq 'scenting material' şeklinde açıklayarak Türkmence qoq sözcüğünün aynı anlamda olduğunu belirtir (1968: 106, § 19). ${ }^{6}$ Clauson da sözcüğü koklık biçiminde ve hap[ax] leg[omenon] 'tek örnek' olarak kaydeder; ancak sözcüğün anlamına ilişkin bir ipuçunun bulunmadığını, sözcüğün kokfiiliyle varsayılan bir bağlantısı dolayısıyla şimdiye kadar 'parfüm' olarak tercüme edildiğini, morfolojik olarak bu fiilden türeyemeyeceğini ve bu anlamı kazanamayacağını belirtir (1972: 610b; ayrıca krş. Nadalyayev vd., 1969: 457b). T. Tekin daha sonra sözcüğün kökenini DLT'deki kok- '(yanan bir şey) koku

\footnotetext{
${ }^{6}$ Bu çalışmanın Türkçe tercümelerinde mevzubahis sözcük addan ad türeten $\{+\mid X k\}$ ekinin örnekleri arasından kaldırılmıştır, krş. Tekin, 2003: 84, § 168 ve Tekin, 2016: 82.
} 
vermek' fiili ile ilişkilendirerek bu fiilden -ı ile isim ve bundan +lık eki kokılık (< kok-I+lık) şeklinin türediğinin düşünülebileceğini ifade eder (1988: 111-112). Sözcük BK G 11'de şu bağlamda geçmektedir:

bukug : totok : ......... kanı : lisün : tay "Bukug Totok [... ...] babası Büyük senün : başad[u] : besş yüz : eren : kelti General Lisün'ün komuta ettiği beş yüz : kokılık : ö[.........] : altun : kümüş : asker geldi. Kokılık [... ...] altın ve kergeksiz : kelürti (Ölmez 2013: 140- gümüşü gereğinden fazlasıyla getirdi." $\left.141_{10-11}\right)$. (Ölmez 2013: 15510-11).

Mevzubahis sözcük muhtelif çalışmalarda şöyle okunmuş ve anlamlandırılmıştır:

\begin{tabular}{|c|c|c|}
\hline Kaynak & $\begin{array}{l}\text { Sözcüğün yazı } \\
\text { çevirimi }\end{array}$ & Anlam \\
\hline Radloff, 1897: 148 & kokылаk <kokılak> & $\begin{array}{l}\text { 'wohlreichende II güzel } \\
\text { kokulu' }\end{array}$ \\
\hline $\begin{array}{l}\text { Thomsen, } 1896 \text { [2002: } \\
\text { 194-195] }\end{array}$ & qoq ${ }^{y \nmid y} q$ & 'parfum || parfüm' \\
\hline Orkun, 1936: 70 & kok"l'k & 'kokuluk' \\
\hline Tekin, 1968: 246 & qoqiilïq & - \\
\hline Tekin, 1988: 54-55 & $\operatorname{kook}(1) \mid(1) k$ & 'kokuluk' \\
\hline Berta, 2010: 175; 199 & qoqlwq & - \\
\hline $\begin{array}{l}\text { Ölmez, 2013: 140; krş. } \\
353 a\end{array}$ & kokılık & 'tütsü' \\
\hline Şirin, 2016: 405 & kokılık & $\begin{array}{l}\text { '(cenaze ritüellerinde } \\
\text { kullanılan) kokuluk, tütsü' }\end{array}$ \\
\hline Aydın, 2017: 98 & kokılık & 'kokulu' \\
\hline
\end{tabular}

küli: Sözcük 'tütsülük, buhurdan' anlamındadır. Kara ve Zieme (1976: 39) sözcüğü Moğ. külis 'tütsü yakıcı, buhurdan' (Lessing, 1960: 501a) ile karşılaştırır. Sözcük Tantra Budizmine ilişkin Eski Uygurca bir metin olan BT VII A'da şu

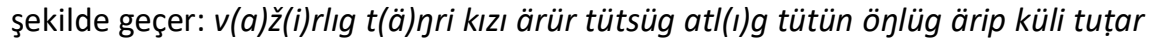
tütsüglüg bulutka oyun bädizkä tükälligig munı üzä kök kalıkıg toşgurup tapınurbiz (Kara ve Zieme, 1976: 39177-179) "Tütsü çubuğu adlı ve duman renkli 
Vajra Tanrılar kızı vardır, bir buhurdan tutar. Biz duman bulutuyla ve süslemelerle 2 göğü doldurup saygı gösteririz." Yüan dönemine ait bir Budist Uygur metninde aynı sözcük kilü olarak okunmuş yine 'buhurdan' anlamı verilmiştir (Tekin, 1980b: 253356).

küži: Sözcük 'tütsü' anlamındadır. Sözcük kökeni itibarıyla Skt. kuśa'ya 'ot, odun parçası' (Monier-Williams, 1899: 297a) dayanır. Moğolcada küci 'tütsü, tütsü çubuğu' (Lessing, 1960: 509b) anlamındadır. Eski Uygurca metinlerde sözcüğün yazı çevirimi küji, küşi, küži olarak yapılmıştır. Bu sözcük metinlerde çoğunlukla kara küži ifadesiyle geçer. Bu söz AYS VII iki yerde tanıklanmıştır: lukura kara küži (Çetin, 2012: 136411) ifadesi Çin. metinde 安息香 anxi xiang (Taishō No. 665, c. 16, 435a07) 'İran tütsüsü veya aselbent' (Soothill ve Hodous, 1937: 212a) karşılığındadır. AYS VI’daki küži (Ayazlı, 2012: 131 883 ) karşılığında Çin. metinde 薰陸 xunlu (Taishō No. 665, c. 16, 430c18) 'boswellia thurifera reçinesi, bir tür tütsü' (DDB) bulunur. Ayrıca AYS VII'de kara küži köyürsün (Çetin, 2012: 138 ${ }_{436}$ 437) “Tütsüler yaksın” ifadesi de mevcuttur. TT V A 129'da da kara küži ifadesine 'aselbent' anlamıyla rastlanır: anta ötrü arvış̧̧ k(a)ra küži alıp yeti kata tarni arvış sözlämiş k(ä)rgäk tütsülük lugta köyürmüş k(ä)rgäk (Bang ve Gabain, 1931: 332128-130; krş. Uzunkaya, 2017: 75 128-130) “Ondan sonra büyücü (eline) aselbent alıp yedi kez dhāraṇi (ve) büyü sözcüğü söylemeli, buhurdanda 2 yakmalı." MaueKat'da da kara küži ifadesi Skt. mahișākșayuktāṃ 'Balsamodendron mukul' (Maue, 1996: 12617) karşılığındadır. küži 'buhur, tütsü' Doğu Kilisesi'ne ilişkin Eski Uygurca metinlerde zmuran küži (B 19) ve zm(u)run küži (B 23) tabiriyle 'mürsafi ve buhur' tanıklanmıştır (Zieme, 2015: 51).

lug: 'Tütsülük, buhurdan' anlamındaki sözcüğün kökeni Çin. 鑪 lu 'a stove; a réchaud; a censer; a brazier' (G. 7416) olup sözcüğe Eski Uygurcada iki yerde rastlanmıştır. Sözcük BT IX'da şu ifadede 'tütsülük, buhurdan' olarak geçer: 
luglarıg birlä k(a)ttım(ı)z kardımız (Tekin, 1980a: 187177.8-9) "Buhurdanları karmakarışık ettik." ПT V A metninde geçen ifade tütsülük lug 'buhurdan ${ }^{\prime}$

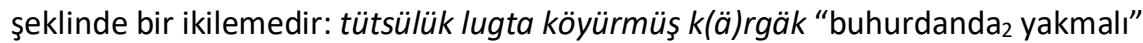
(Bang ve Gabain, 1931: 332 130 ve ayrıca krş. Uzunkaya, 2017: 75130).

lukura: AYS VII'de geçen lukura kara küži ifadesinin Çin. metindeki karşılığı 安息香骞具攞 anxi xiang jujuluoluo (Taishō No. 665, c. 16, 435a07; Çetin, 2012: 205) şeklindedir. kara küži sözüne 安息香anxi xiang karşılık gelirken, lukura sözüne 軋具攞 jujuluoluo karşılık gelmektedir. lukura 'İran tütsüsü' Skt. guggula (DDB) karşılığındadır. Skt. bu ifade 'bdellium || bir çeşit kokulu reçine' (MonierWilliams, 1899: 356b) anlamındadır.

tupi(m?): Sözcüğün kökeni Skt. dhūpa 'tütsü, parfüm, aromatik buğu' (MonierWilliams, 1899: 517c; Zieme ve Kara, 1978: 260b) sözüdür. Sözcüğe UigTot.'ta 'tütsü' (Zieme ve Kara, 1978: 1881385) anlamıyla ve $2009<$ twpy $>(62 a 9)$ yazımıyla rastlanır.

tütsüg: Clauson sözcüğe 'tütsü' anlamını verir ve *tützüg'ün ikincil bir şekli olabileceğinden bahseder. Buna göre sözcük tütüz- fiilinden türemiştir (Clauson, 1972: 461a; ayrıca krş. Nadalyayev vd., 1969: 601b). OTWF'de sözcüğe tützük olarak yer verilir. Erdal, tützük biçimi sadece bir yerde tanıklanmış olsa da bu biçimin arkaik olduğunu belirterek sözcüğün yapısını tüt-üz- olarak açıklar ve bununla beraber /z/'nin her yerde /s/'ye değiştiğini ifade eder. tützük, tütüzfiilinin nesnesini gösterir (Erdal, 1991: 251; ayrıca eklerde /z/'leşme bahsinin tüt-üz- 'tüttürmek' örneği için krş. Tekin, 2000: 6). Bu açıklamalar ışığında sözcüğün yapısı tüt-üz-üg şeklinde açıklanabilir. Sözcüğe HT V'te dört yerde rastlanır. Bunlardan birkaçı şöyledir: mokşadeve tep tesär [kur]tulmaknın t(ä)நrisi tep [teyü]r tütsüg küyürdilär [hua] saçtılar yüküntilär [tapın]tılar samtso açari ymä [tü]tsüg küyürüp hua saçıp [y]ükünüp agır ayag kılıp öni [bar]dı (Dietz, 
Ölmez ve Röhrborn, 2015: 112-113858-865) "Mokșadeva kurtuluş Tanrısı demektir. Tütsü yaktılar, çiçek ${ }_{2}$ saçtılar, önünde eğilip saygı gösterdiler. Tripițaka ustası da tütsü yakıp, çiçek saçıp, secde edip, büyük bir saygı gösterip gitti." Buradaki Uyg. tütsüg küyür- karşılığında Çin. metinde 燒香 shaoxiang 'tütsü yakmak' (Taishō No. 2053, c. 50, 248a10; DDB) ifadesi geçmektedir. HT V'te sözcüğün geçtiği bir diğer yer ise şudur: önin önin tütsü[g] hua çäçäk tuta bir uçlug könülin kut koltılar (Dietz, Ölmez ve Röhrborn, 2015: 2352233-2236) “Ayrı ayrı tütsü, çiçek tutarak yoğunlaştırılmış bir gönülle kutsallık dilediler." Burada Uyg. tütsüg karşılığında Çin. metinde 燒香 shaoxiang 'tütsü yakmak' (Taishō No. 2053, c. 50, 251c04; DDB) ifadesi geçer. HT VII'de geçen tütsüg tut- (Röhrborn, 1991: $107_{1183}$ ) ifadesinin karşılığı Çin. metinde 執香爐 zhi xianglu (Taishō No. 2053, c. 50, 259c19; DDB) 'tütsülük tutmak'tır (Semet, 2005: 173). Burada Uyg. metindeki tütsüg karşılığında Çin. metinde 香爐 xianglu 'tütsülük' (DDB) geçer. HT VIII 1434'te geçen tütsüg yorıt- sözü karşılığında Çin. metinde 行香 xingxiang 'tütsü(yü) elden ele dolaştırmak' (Taishō No. 2053, c. 50, 266a13; Semet, 2005: 173) tabiri bulunmaktadır. Sözcük bunlar dışında burda birkaçını sayabileceğimiz AYS IV [2757], AYS V [130, 407], AYS VI [0486, 0493 vd.], AYS VII $[428,677,679]$ gibi Eski Uygurca metinde de tanıklanır. KB'de tütsüg bir yerde 'tütsü' anlamıyla tanıklanır (Ata, 1979: 483).

tütsüglük: Sözcüğün yapısı tüt-üz-üg+lük biçiminde açıklanabilir. Clauson sözcüğü 'buhurdan' olarak anlamlandırır (1972: 461a; ayrıca krş. Nadalyayev vd., 1969: 601b). Sözcüğe AYS VI'da bir yerde rastlanır ve buradaki ifadenin Çin. eş değer metindeki karşılığı olarak 香爐 xianglu (Taishō No. 665, c. 16, 430c19) 'tütsülük, buhurdan' bulunur: yaワı arıg ton kädip äligintä tütsüglük tuta bo

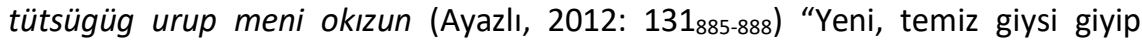
elinde buhurluk tutarak bu tütsüyü yakıp beni çağırsın” (Ayazlı, 2012: 175). BT 
XXIII'te sözcüğe elgintä tütsüglük tutar "Elinde buhurdan tutar." ifadesinde rastlanır (Zieme, 2005: 73 $\left.{ }_{\mathrm{D} 107}\right)$. Bununla birlikte BT IX'da da sözcüğe rastlanır: tütsüglük tutup ävinin kapagınta ulug agır ayamakın kelteçi dentarlarıg (Tekin, 1980a: 22294.6-7) “Buhurdan tutup evinin kapısına büyük bir saygıyla gelecek din adamları".

yıpar: Clauson kin sözcüğü ile yıpar sözcüğü arasındaki ilişkinin muğlak olduğunu, kin'in her zaman misk geyiği ve misk sıçanı salgısı 'misk' anlamında olduğunu ve yıpar'ın aslında daha genel olarak misk ve çiçek benzeri şeyler için yı $\underline{d}$ yıpar ikilemesinde 'rayiha, ıtır' anlamında göründüğünü ve erken dönemde 'misk' için özelleştiğini belirtir (1972: 878b-879a). Doerfer sözcüğe ïpār (ايڤٌ) 'Thymian, Ysop (thymus, satureia) || kekik otu, zulfa otu' olarak yer verir ve en eski metinlerde ve sonraki kaynaklarda yıpar olarak tanıklandığını belirtir. Sözcüğün birkaç durumda 'wohlreichende Pflanze || güzel kokulu bitki' anlamında olduğunu belirterek (Doerfer, 1965: 2-3, § 411) DS'deki ipar 'yüksek dağların kar tutmayan yerlerinde yetişen bir çeşit dikenli otun, kurusa bile kokusu uzun zaman gitmeyen sarımtırak çiçekleri, misk, amber (Urfa, Antalya)' (1974: 2546a) sözcügüne atıf yapar. TS'de ıpar sözcüğüne 'yavşan denilen güzel kokulu ot' anlamıyla yer verilir (22009: 110a). DS'de ıpar'ın yanı sıra yıpar 'güzel koku (İçel köyleri)' sözüne de rastlanır (1972: 4275a). Bu sözcük kağanlık yazıtlarından BK G 11'de tanıklanmıştır:

yog : yıparıg : kelürüp : tike : bèrti : "Cenaze için tütsü getirip dikti. Sandal çıntan : ıgaç : kelürüp : öz yar[.........] ağacı getirip kendisi [... ... cenaze bonça : bodun : saçin : kulkakin : töreni sırasında] bunca insan saçını, [b]ıçdı edgü özlik atin : kara kişin : kök kulağını kesti, kendi şahsi atlarını, kara : tèyegin : sansız : kelürüp : $k^{\circ} o p:$ samur, boz sincap (derilerini) sayısız kodtı (Ölmez, 2013: 141 111-12). getirip hepsini hediye ettiler." (Ölmez, 
2013: $155_{11-12)}$.

Muhtelif çalışmalarda sözcük şu şekilde okunmuş ve anlamlandırılmıştır:

Kaynak

Radloff, 1897: 148

Thomsen, 1896 [2002 194-195]

Orkun, 1936: 70

Tekin, 1988: 54-55

Berta, 2010: 175; 199

Ölmez, 2013: 141, 155

Şirin, 2016: 406

Aydın, 2017: 98
Sözcüğün yazı

Anlam

\section{çevirimi}

jо5 јышанық [yog 'Begräbnissgeräthe (?) ||
yıparıg] cenaze gereci (?)'

yıparıg]

(?)'

yug y'parig

'cenaze mumları (?)'

yog yıp(a)r(ı)g

yoy yıparıy

yog yıparıg

yıpar

'cenaze mumları'

'tören için misk'

'cenaze için tütsü'

'(cenaze ritüellerinde

kullanılan) kokulu mum,

tütsü'

yog $y^{2}$ ıparıg

Dağlık Altay Bölgesi yazıtlarında da bu söze bir kez Kalbak-Taş XVII (A-40)'de rastlanır; ancak burada sözcüğün " $y(ı) p(a) r-a$ " mı " $y(a) p(a) r-a$ ” mı olduğu kesin değildir:

$t(a) b g(a) c ̧-a \quad y(ı) p(a) r-a$ / y(a)p(a)r-a "Çin tütsüleri / Çinliler (bir şeyi) (Tıbıkova, Nevskaya ve Erdal, 2012: 86; yapar." (Mozioğlu, 2016: 257)

Mozioğlu, 2016: 257) 
Sözcük çoğu Eski Uygurca metinlerde yıd yıpar ikilemesiyle geçmektedir ve bu noktada Çin. metindeki karşılığıyla 'tütsü' olarak yer almaktadır. HT III'te geçen yıd yıpar hua çäçäk (Ölmez ve Röhrborn, 2001: 126904-905) 'tütsü ve çiçek ${ }_{2}$ ifadesinin Çin. metindeki karşılığı 香花 xianghua 'tütsü ve çiçek' (Taishō No. 2053, c. 50, 239c11; DDB) olarak geçmektedir. HT V'teki yıd yıpar hua çäçäk (Dietz, Ölmez ve Röhrborn, 2015: 226 2136 ) 'tütsü2 ve çiçek2' ikilemesinin Çin. metindeki karşılığı 香花 xianghua 'tütsü ve çiçek' (Taishō No. 2053, c. 50, 251b11; DDB) bulunmaktadır. HT V'teki bir diğer ifade olan hua çäçäki[n yıd] yıparın (Dietz, Ölmez ve Röhrborn, 2015: 66 $333-334$ ) 'çiçek 2 ve güzel kokuyla2' ikilemesinin Çin. metindeki karşılığı olarak 花香 hua xiang 'çiçek ve tütsü' (Taishō No. 2053, c. 50, 246c09; DDB) yer alır. HT VII'de geçen yı[d] yıpar hua çäçäk (Röhrborn, 1991: 1031136-1137; Semet, 2005: 173) "tütsü 2 ve çiçek2" ifadesinin Çin. metindeki karşılığı 香花 xianghua 'tütsü ve çiçek'tir (Taishō No. 2053, c. 50, 259c10; DDB). HT VIII'de geçen yıpar yügmäk burhan uluşı (Röhrborn, 1996: 162 1857 ) 'koku yığan Buddha'nın ülkesi' ifadesinin Çin. metindeki karşılığı 香積 xiangji (Taishō No. 2053, c. 50, 267a17) 'kokular ülkesinin Buddhası'dır (DDB). AYS IV'teki tüü törlüg aḍrok aḍrok yıḍ yıpar hua çäçäklär (Tokyürek, 2018: 32419-20) ifadesindeki yıḍ yıpar karşılığında da Çin. metinde 香 xiang (Taishō No. 665, c. 16, 417c25) bulunur. KB'de yıpar 'misk' sözcüğü on yerde tanıklanmıştır (Arat, 1979: 540) ve ayrıca sözcüğe kin yıpar şekliyle 'misk göbeği' anlamıyla ikileme olarak rastlanır (Taş, 2012: 60). DLT'de yıpar sözü Ar. misk (Dankoff ve Kelly, 1984: 161, sh. 456) sözüyle karşılanmıştır. Bunun dışında DLT'de yıpar sözcüğünün oluşturduğu şu birleşik kullanımlar da mevcuttur: yıpar saç- 'misk saçmak' (Dankoff ve Kelly, 1982: 389, sh. 265), yıpar

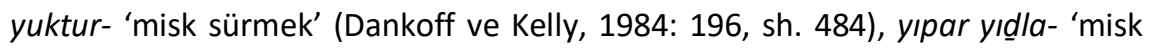
koklamak' (Dankoff ve Kelly, 1984: 307, sh. 579). 


\section{SONUÇ}

Eski Türkçenin söz varlığının tematik olarak analizi Türklerin içinde bulunduğu kültürel çevrenin sınırlarının belirlenebilmesi için önem arz etmektedir. Bunun aynı zamanda karşılaştırmalı analizi tarihî ve modern Türkçedeki anlam değişmelerine de ışık tutabilmektedir. Bununla ilişkili olarak Eski Türkçe metinlerin söz varlığının daha iyi anlaşılabilmesi bu metinlerin orijinal metinleriyle ve/veya kaynak dillerdeki biçimleriyle incelemeyi gerektirir. Bir tercüme edebiyat olan Eski Uygurcada bu noktada Çince orijinal metinlerden yardım almak daha doğru bir anlamlandırma ve değerlendirmeyi mümkün kılmaktadır. Eski Türkçe metinlerin orijinal metinleri yahut iki dilli hazırlanmış olan tarihî sözlükler çoğu zaman anlaşılması güç ifadelerde kilit rol üstlenmektedir. Buna ilaveten Türk dilini söz konusu eden farklı dillerde kaleme alınmış eserler de Türkçe söz varlığının anlam dünyasını aydınlatır.

Eski Türkçe dönemi metinlerinde kokuya dair ifadeler için bur- 'kokmak', kapir 'kâfur', kin yıpar 'misk', kinlig 'misk kokulu', kisarlıg 'güzel kokulu', köti'kokmak, koku salmak', sagbıç 'bir çeşit sıvı koku', sası- 'kötü kokmak', sasıg 'pis kokulu', şaruki 'bir tür koku', tagar 'hoş kokulu toz', tütit- 'duman sızmak veya buhar çıkarmak', tütnä- 'tütmek', yıd 'güzel koku, rayiha', yıdı- 'kötü kokmak', yıdıg 'kötü koku', yıdışka- 'kokmak', yıdıt- 'kokutmak', yıdla- 'koklamak' ve yıdlıg 'güzel kokulu' tespit edilmiştir. Kokuya ilişkin tespit edilen bu yirmi ifadeden dördü kapir, sagbıç, şaruki ve tagar Sanskritçe kökenlidir. kisarlıg ifadesi Sanskritçe kökene Türkçe bir ekin gelmesinden oluşmuştur; bu bakımdan Sanskritçe ve Türkçe birleşik yapıdadır. Yine bu dönem metinlerinde tütsü ve buhurdan anlamında geçen ifadeler için käräşü 'tütsü', kokılık 'tütsü', küli 'tütsülük, buhurdan', küži 'tütsü, tütsü çubuğu', lug 'tütsülük', lukura 'tütsü', tupi(m?) 'tütsü', tütsüg 'tütsü' ve yıpar 'tütsü' olmak üzere dokuz ifade tespit 
edilmiştir. Bu dokuz ifadeden küli Moğolca, küži, lukura ve tupi(m?) Sanskritçe, lug ise Çince kökenlidir.

Eski Türkçede koku, tütsü ve buhurdan anlamına gelen sözcüklerin etimolojisini ve orijinal metinlerdeki biçimlerinin tespit edildiği bu çalışma ile Türk dilinin ve Türklerin farklı coğrafyalarda farklı kültürlerle, dillerle ve dinlerle olan irtibatı gösterilmeye çalışılmıştır. Çalışmanın gövdesini oluşturan inceleme kısmında da görüldüğü üzere koku, tütsü ve buhurdan anlamına gelen sözlerin birçoğu Türkçe kökenli olsa da Orta Asya'da yaşamış veya Türklerin irtibatta bulundukları toplulukların dillerinden ödünçlenmiş ifadeleri de içermektedir. Özellikle koku gibi kavram alanına ilişkin ifadelerin somutlaştırılabilmesinde ve anlamlandırılabilmesinde bu ve benzeri çalışmalar önemli bir adım olarak görülebilir.

\section{KISALTMALAR}

AdW

Akademie der Wissenschaften

AF

Asiatische Forschungen

AKDTYK

Atatürk Kültür, Dil ve Tarih Yüksek Kurumu

Ar.

Arapça

AYS IV

Altun Yaruk Sudur VI. Tegzinç (Karşılaştırmalı Metin

Yayını), bk. Tokyürek 2018

AYS V

Altun Yaruk Sudur V. Kitap Berlin Koleksiyonundaki

Fragmanların Transliterasyonu ve Transkripsiyonu

Açıklamalar ve Dizin, bk. Uçar 2009

AYS IX

Uygurca Altun Yaruk Sudur, IX. Kitap. Diplomatik

Neşir Usûlüyle Yayını, Tercüme Açıklamalar ve Dizin,

bk. Uçar 2013

AYS VI

Altun Yaruk Sudur VI. Kitap Karşılaştırmalı Metin 
AYS VII

Yayını, bk. Ayazlı 2012

BBAW

Altun Yaruk Yedinci Kitap Berlin Bilimler

Akademisindeki Metin Parçaları Karşılaştırmalı

Metin, Çeviri, Açıklamalar, Dizin, bk. Çetin 2012

Berlin-Brandenburgische Akademie der

Wissenschaften

BK G

Bilge Kağan Yazıtı güney yüzü

BK K

Bilge Kağan Yazıtı kuzey yüzü

BT

Berliner Turfantexte

BT III

Das uigurische Insadi-Sūtra, bk. Tezcan 1974

BT IX

Maitrisimit nom bitig: Die uigurische Übersetzung eines Werkes der buddhistischen Vaibhāșika-Schule, bk. Tekin 1980

BT XXIII

Magische Texte des uigurischen Buddhismus, bk. Zieme 2005

BT XXV

Das Buch von der Sündentilgung. Edition des alttürkisch-buddhistischen Kšanti Kılguluk Nom Bitig, bk. Wilkens 2007

BT XXXIII

A Study of the Buddhist Sūtra called Säkiz Yükmäk Yaruq or Säkiz Törlügin Yarumï̌ Yaltrïmïš in Old Turkic, bk. Oda 2015

BT XXXVII

Buddhistische Erzählungen aus dem alten Zentralasien. Edition der altuigurischen Daśakarmapathāvadānamālā, bk. Wilkens 2016

c. cilt

Çin.

Çince

DDB

Digital Dictionary of Buddhism

DLT

Dīvānu Luġāti't-Türk 
DS

düz.

G

HT V

HT VII

HT VIII

HT IX

HT X

KB

MaueKat

Moğ.

No.

OTWF

SEDTF 2
Derleme Sözlüğü

düzenleyen

A Chinese-English Dictionary, bk. Giles 1912

Die alttürkische Xuanzang-Biographie V, bk. Dietz, Ölmez ve Röhrborn 2015

Die alttürkische Xuanzang-Biographie VII, bk. Röhrborn 1991

Die alttürkische Xuanzang-Biographie VIII, bk. Röhrborn 1996

Die alttürkische Xuanzang-Biographie IX, bk. Aydemir 2013

Die alttürkische Xuanzang-Biographie $X$, bk. Mirsultan 2010

Kutadgu Bilig

Alttürkische Handschriften. Teil 1: Dokumente in Brāhmī und tibetischer Schrift, bk. Maue 1996

Moğolca

numara

Old Turkic Word Formation. A Functional Approach to the Lexicon, bk. Erdal 1991

Sprachwissenschaftliche Ergebnisse der deutschen

Turfan-Forschung. Text-Editionen und Interpretationen von Albert August von Le Coq, Friedrich Wilhelm Karl Muller, Willi Bang, Annemaie von Gabain, Gabdul Rašid Rachmati, Wilhelm Thomsen. Gesammelte Berliner Akademieschriften 1908-1938. Mit Vorwort von Georg Hazai. Band 2. Mit 15 Tafeln. Leipzig 1972. (Opuscula. 
Sammelausgaben seltener und bisher nicht selbststandig erschienener wissenschaftlicher Abhandlungen. 3, 2.)

SGKAO Schriften zur Geschichte und Kultur des Alten Orients

Skt.

Sanskritçe

sh.

sahife

SPAW

Sitzungsberichte der Preusischen Akademie der Wissenschaften

TDK

Türk Dil Kurumu

TIEM

Türk İslam Eserleri Müzesi

TKAE

Türk Kültürünü Araştırma Enstitüsü

TS

Tarama Sözlüğü

TT V A

Türkische Turfan-Texte V, bk. Bang ve Gabain 1931;

Uzunkaya 2017

Tü.

Türkçe

UigTot.

Ein uigurisches Totenbuch, bk. Zieme ve Kara 1978

Uyg.

Eski Uygurca

vd.

ve diğerleri

VdSUA

Veroffentlichungen der Societas Uralo-Altaica

VOHD

Verzeichnis der Orientalischen Handschriften in

Deutschland

vr. varak

yay.

yayın(ları)

ZAGA

Zentralinstitut fur Alte Geschichte und Archaologie 


\section{KAYNAKÇA}

Arat, R. R. (1979). Kutadgu Bilig III Indeks. (İndeksi neşre hazırlayanlar: Kemal Eraslan, Osman F. Sertkaya, Nuri Yüce). İstanbul. (TKAE Yay. 47, IV - A 12.)

Ata, A. (1997). Nāșırü'd-dīn bin Burhānü'd-dīn Rabg்ūzī K়ıșașüll-Enbiyā (Peygamber Kıssaları). I (Giriş-Metin-Tıpkıbasım), II (Dizin). Ankara: Türk Dil Kurumu Yay. (AKDTYK. TDK Yay. 681-1, 681-2.)

Ata, A. (1998). Nehcü'l-Ferādis Uştmahhlarnıng Açuḳ Yolı Cennetlerin Açık Yolu III Dizin- Sözlük. Ankara: Türk Dil Kurumu Yay. (AKDTYK. TDK Yay. 518.)

Ayazlı, Ö. (2012). Altun Yaruk Sudur VI. Kitap Karşılaştırmalı Metin Yayını. Ankara: Türk Dil Kurumu Yay. (AKDTYK. TDK Yay. 1051. Eski Uygurca Kütüphanesi. 1)

Ayazlı, Ö. (2016). Eski Uygurca Din Dışı Metinlerin Karşılaştırmalı Söz Varlığı. Ankara: Türk Dil Kurumu Yay. (AKDTYK. TDK Yay. 1187. Eski Uygurca Kütüphanesi. 5)

Aydemir, H. (2013). Die alttürkische Xuanzang-Biographie IX. Nach der Handschrift von Paris, Peking und St. Petersburg sowie nach dem Transkript von Annemarie v. Gabain ediert, übersetzt und kommentiert. Band I-II. Wiesbaden: Harrassowitz. (Xuanzangs Leben und Werk. 10. VdSUA. 34.)

Aydın, E. (2017). Orhon Yazıtları (Köl Tegin, Bilge Kağan, Tonyukuk, Ongi, Küli Çor). İstanbul: Bilge Kültür Sanat. 
Bang, W. ve A. von Gabain (1931). Türkische Turfan-Texte V. Aus buddhistischen Schriften. Berlin. (SPAW. Phil.-hist. KI. 1931: 14. 323-356.) [Tıpkıbasımı: SEDTF 2, 99-132.]

Berta, Á. (2010). Sözlerimi lyi Dinleyin: Türk ve Uygur Runik Yazıtlarının Karşılaştırmalı Yayını. Çev., Emine Yılmaz. Ankara: Türk Dil Kurumu Yay. (AKDTYK. TDK Yay. 1008.)

Boeschoten, H. E. ve J. O'Kane (2015). Al-Rabghūzī, The Stories of the Prophets Qișaș al-Anbiyā': An Eastern Turkish Version (Second Edition). Volume 1 - Text Edition, Volume 2 - Translation. Leiden \& Boston: Brill.

Caferoğlu, A. (1931) Abû-Hayyân Kitâb al-Idrâk li-lisân al-Atrâk. İstanbul: Evkaf Matbaası.

Çetin, E. (2012). Altun Yaruk Yedinci Kitap Berlin Bilimler Akademisindeki Metin Parçaları Karşılaştırmalı Metin, Çeviri, Açıklamalar, Dizin. Adana: Karahan Kitabevi.

Clauson, Sir G. (1972). An Etymological Dictionary of Pre-Thirteenth-Century Turkish. Oxford: Oxford at the Clarendon Press.

Dankoff, R. ve J. Kelly (1982-1985). Maḥmūd al-Kāšyarī. Compendium of Turkic Dialects (Dīwān Luyāt at-Turk). Part I-III. Duxbury, Massachusetts: Harvard University. (Sources of Oriental Languages and Literatures. 7. Turkish Sources. VII.)

DDB = Digital Dictionary of Buddhism, www.buddhism-dict.net/ddb/ (07.10.2019) 
Dietz, Siglinde, M. Ölmez, K. Röhrborn (2015). Die alttürkische XuanzangBiographie VII. Nach der Handschrift von Leningrad, Paris und Peking sowie nach dem Transkript von Annemarie von Gabain hrsg., übersetzt und kommentiert. Wiesbaden: Harrassowitz. (Xuanzangs Leben und Werk. 11. VdSUA. 34.)

Dilçin, C. (düz.) (22009). Yeni Tarama Sözlüğü. Ankara: Türk Dil Kurumu Yay. (AKDTYK. TDK Yay. 503.)

Doerfer, G. (1963-1975) Türkische und mongolische Elemente im neupersischen. Unter besonderer Berücksichtigung älterer neupersischer Geschichtsquellen, vor allem der Mongolen- und Timuridenzeit. 1. Mongolische Elemente im Neupersischen [1963]. 2. Türkische Elemente im Neupersischen: alif bis tā [1965]. 3. Türkische Elemente im Neupersischen: ğīm bis kāf [1967]. 4. Türkische Elemente im Neupersischen (Schluss) und Register zur Gesamtarbeit [1975]. Wiesbaden. (Akademie der Wissenschaften und der Literatur [Mainz]. Veroffentlichungen der Orientalischen Kommission. 16, 19, 20, 21.)

Edgerton, F. (1953). Buddhist Hybrid Sanskrit Grammar and Dictionary, c. II: Dictionary. New Haven: Yale University Press.

Erdal, M. (1991). Old Turkic Word Formation. A Functional Approach to the Lexicon. Vol. I-II. Wiesbaden: Harrassowitz. (Turcologica 7.)

Giles, H. A. (1912). A Chinese-English Dictionary. Part I-II. 2. bs. Shanghai/London: Kelly and Walsh.

Hirakawa, A. (1997). A Buddhist Chinese-Sanskrit Dictionary. Tōkyō: Reiyukai. 
Kara, G. ve P. Zieme (1976). Fragmente tantrischer Werke in uigurischer Übersetzung. Berlin: Akademie-Verlag. (AdW der DDR. ZAGA. SGKAO. BT. 7.)

Karaayak, T. (2017). Eski Uygurca Abitaki Metinlerinin Sözvarlığı. Yayımlanmamış yüksek lisans tezi, Yıldız Teknik Üniversitesi Sosyal Bilimler Enstitüsü, İstanbul.

Khairullah, H. L. (2015). Et-Tuhfetü'z-Zekiyye fi'l-Luġati't-Türkiyye Çeviri-Fiil incelemesi. Yayımlanmamış doktora tezi, Yıldız Teknik Üniversitesi Sosyal Bilimler Enstitüsü, İstanbul.

Kök, A. (2004). Karahanlı Türkçesi Satır-arası Kur'an Tercümesi (TiEM $731 v$ 235v/2) Giriş-inceleme-Metin-Dizin. Yayımlanmamış doktora tezi, Ankara Üniversitesi Sosyal Bilimler Enstitüsü, Ankara.

Kormuşin, İ., E. Mozioğlu, R. Alimov, F. Yıldırım (2016). Yenisey-Altay-Kırgızistan Yazıtları ve Kâğıda Yazılı Runik Belgeler. Ankara: BilgeSu Yayıncılık.

Lessing, F. D. [ed.] (1960). Mongolian-English Dictionary. Bloomington.

Maue, D. (1996). Alttürkische Handschriften. Teil 1: Dokumente in Brāhmī und tibetischer Schrift. Beschrieben und hrsg. Stuttgart: Steiner. (VOHD. 13, 9.)

Mirsultan, A. (2010). Die alttürkische Xuanzang-Biographie X. Nach der Handschrift von Paris, Peking und St. Petersburg sowie nach dem Transkript von Annemarie v. Gabain ediert, übersetzt und kommentiert. Wiesbaden: Harrassowitz. (Xuanzangs Leben und Werk. 9. VdSUA. 34.) 
Monier-Williams, M. (1899). A Sanskrit-English Dictionary. Oxford: Oxford University Press.

Mutçalı, S. (2012). Arapça-Türkçe Sözlük. İstanbul: Dağarcık.

Nadalyayev, V. M., D. M. Nasilov, E. R. Tenişev, A. M. Şcerbak (1969). Drevnetyurkskiy Slovar'. Leningrad: Izdat. Nauka, Leningradskoe Otd. (Akademiya Nauk SSSR. Institut Yazıkoznaniya).

Oda, J. (2015). A Study of the Buddhist Sūtra called Säkiz Yükmäk Yaruq or Säkiz Törlügin Yarumï̌ Yaltrïmïš in Old Turkic. Turnhout: Brepols. (BBAW. Akademienvorhaben Turfanforschung. BT. 33.)

Ölmez, M. (2013). Orhon-Uygur Hanlığı Dönemi Moğolistan'daki Eski Türk Yazıtları (Metin-Çeviri-Sözlük). Ankara: BilgeSu Yayıncılık.

Ölmez, M. ve K. Röhrborn (2001). Die alttürkische Xuanzang-Biographie III. Nach der Handschrift von Leningrad, Paris und Peking sowie nach dem Transkript von Annemarie von Gabain hrsg., übersetzt und kommentiert. Wiesbaden: Harrassowitz. (Xuanzangs Leben und Werk. 7. VdSUA. 34.)

Orkun, H. N. (1936). Eski Türk Yazıtları I. İstanbul: Devlet Basımevi.

Özyetgin, A. M. (2001). Ebū Hayyān Kitābu'l-idrāk li Lisāni'l-Etrāk Fiil: Tarihî Karşılaştırmalı Bir Gramer ve Sözlük Denemesi. Ankara: KÖKSAV. (Tengrim Türklük Bilgisi Araştırmaları Dizisi. 3)

Radloff, W. (1897). Die alttürkischen Inschriften der Mongolei, neue Folge, nebst einer Abhandlung von W. Barthold: die historische Bedeutung der 
alttürkischen Insch-riften. St. Petersburg: Buchdruckerei der kaiserlichen Akademie der Wissenschaften.

Röhrborn, K. (1991). Die alttürkische Xuanzang-Biographie VII. Nach der Handschrift von Leningrad, Paris und Peking sowie nach dem Transkript von Annemarie von Gabain hrsg., übersetzt und kommentiert. Wiesbaden: Harrassowitz. (Xuanzangs Leben und Werk. 3. VdSUA. 34.)

Röhrborn, K. (1996). Die alttürkische Xuanzang-Biographie VIII. Nach der Handschrift von Leningrad, Paris und Peking sowie nach dem Transkript von Annemarie von Gabain hrsg., übersetzt und kommentiert. Wiesbaden: Harrassowitz. (Xuanzangs Leben und Werk. 5. VdSUA. 34.)

Semet, A. (2005). Lexikalische Untersuchungen zur uigurischen XuanzangBiographie. Wiesbaden: Harrassowitz. (Xuanzangs Leben und Werk. 8. VdSUA. 34.)

Shōgaito, M. (2008). Uighur Abhidharma Texts: A Philological Study. Shuokadoh.

Shōgaito, M. (2014). The Uighur Abhidharmakośabhāșya preserved at the Museum of Ethnography in Stockholm. Harrassowitz Verlag: Wiesbaden. (Turcologica. 99)

Soothill, W. E. ve L. Hodous (1937). A Dictionary of Chinese Buddhist Terms: with Sanskrit and English Equivalents and a Sanskrit-Pali Index. London: Kegan Paul, Trench, Trubner \& Co.

Şirin, H. (2016). Eski Türk Yazıtları Söz Varlığı Incelemesi. Ankara: Türk Dil Kurumu Yay. (AKDTYK. TDK Yay. 1181.) 
Taş, İ. (2012). Kutadgu Bilig'de İkilemeler, Türk Dili Araştırmaları Yıllığı-Belleten 2012/2: 43-95.

Taş, İ. (2015). Kutadgu Bilig'de Söz Yapımı. Ankara: Türk Dil Kurumu Yay. (AKDTYK. TDK Yay. 984)

Tekin, Ş. (1980a). Maitrisimit nom bitig: Die uigurische Übersetzung eines Werkes der buddhistischen Vaibhāșika-Schule. 1. Transliteration, Übersetzung, Anmerkungen. 2. Analytischer und rückläufiger Index. Berlin: Akademie-Verlag. (AdW der DDR. ZAGA. SGKAO. BT. 9.)

Tekin, Ş. (1980b). Buddhistische Uigurica aus der Yüan-Zeit. Budapest: Akadémiai Kiadó. (Bibliotheca Orientalis Hungarica. XXVII.)

Tekin, T. (1968). A Grammar of Orkhon Turkic. Bloomington: Indiana University.

Tekin, T. (1988). Orhon Yazıtları. Ankara: Türk Dil Kurumu Yayınları. (AKDTYK. TDK Yay. 540.)

Tekin, T. (1995). Türk Dillerinde Birincil Uzun Ünlüler. Ankara: Simurg. (Türk Dilleri Araştırmaları Dizisi. 13)

Tekin, T. (2000). “Ana Türkçe'de z'leşme ve s'leşme”, XIII. Dilbilim Kurultay Bildirileri 13-15 Mayıs 1999: 1-12. İstanbul: Boğaziçi Üniversitesi Yayınevi.

Tekin, T. (2016). Orhon Türkçesi Grameri. Ankara: Türk Dil Kurumu Yayınları.

Tezcan, S. (1974). Das uigurische Insadi-Sūtra. Berlin: Akademie-Verlag. (AdW der DDR. ZAGA. SGKAO. 6. BT. 3.) 
Thomsen, V. (1896 [2002]) Orhon Yazıtları Araştırmaları: [1] Orhon ve Yenisey Yazıtlarının Çözümü IIlk Bildiri; [2] V. Thomsen Tarafından Çözülmüş Orhon Yazıtları; [3] Yenisey Yazıtlarındaki lyi Değerlendirilmemiş Bir Harf; [4] Turcica. (çeviren ve yayım hazırlayan: Vedat Köken), Ankara: Türk Dil Kurumu Yay. (AKDTYK. TDK Yay. 815.)

Tıbıkova, L. N., I. A. Nevskaya, M. Erdal (2012). Katalog Drevnetyurkskih Runiçeskih Pamyatnikov Gornogo Altaya. Gorno-Altaysk.

Tokyürek, H. (2018). Altun Yaruk Sudur VI. Tegzinç (Karşılaştırmalı Metin Yayını). Ankara: Türk Dil Kurumu Yay. (AKDTYK. TDK Yay. 1268. Eski Uygurca Kütüphanesi. 8)

Türk Dil Kurumu (1972). Türkiye'de Halk Ağzından Derleme Sözlüğü VI, Ankara.

Türk Dil Kurumu (1974). Türkiye'de Halk Ağzından Derleme Sözlüğü VII, Ankara.

Uçar, E. (2009). Altun Yaruk Sudur V. Kitap Berlin Koleksiyonundaki Fragmanların Transliterasyonu ve Transkripsiyonu Açıklamalar ve Dizin. Yayımlanmamış Doktora Tezi. Ege Üniversitesi, Sosyal Bilimler Enstitüsü, Türk Dünyası Araştırmaları Ana Bilim Dalı, Türk Dili ve Lehçeleri Bilim Dalı, İzmir.

Uçar, E. (2013). Uygurca Altun Yaruk Sudur, IX. Kitap. Diplomatik Neşir Usûlüyle Yayını, Tercüme Açıklamalar ve Dizin. İzmir: Dinazor Kitabevi Yayınları.

Uzunkaya, U. (2017). Son Dönem Budist Uygur Edebiyatından Iki Örnek (MetinÇeviri-Açıklamalar-Dizin). Yayımlanmamış doktora tezi, Yıldız Teknik Üniversitesi Sosyal Bilimler Ensitüsü, İstanbul. 
Wilkens, J. (2007). Das Buch von der Sündentilgung. Edition des alttürkischbuddhistischen Kšanti Kılguluk Nom Bitig. Teil 1. [Vorwort, Einleitung, Edition]. Teil 2. [Glossar, Transliterationen, Tafeln]. Turnhout: Brepols. (BBAW. Akademienvorhaben Turfanforschung. BT. 25, 1 ve 2.)

Wilkens, J. (2016). Buddhistische Erzählungen aus dem alten Zentralasien. Edition der altuigurischen Daśakarmapathāvadānamālā. Teil 1. [Vorwort, Einleitung, Siglen der Handschrift und Konkordanzen, Edition]. Teil 2. [Edition, Faksimiles] Teil 3. [Glossar, Transliterationen, Abkurzungen, Literaturverzeichnis]. Turnhout: Brepols. (BBAW. Akademienvorhaben Turfanforschung. BT. 37, 1, 2 ve 3.)

Yıldırım, F. (2017). Irk Bitig ve Orhon Yazılı Metinlerin Dili. Ankara: Türk Dil Kurumu Yay. (AKDTYK. TDK Yay. 1244. Eski Uygurca Kütüphanesi. 7)

Yüce, N. (1993). Ebu'l-Ḳāsım Cārullah Maḥmūd bin 'Omar bin Muhammed bin Aḥmed ez-Zamahşsarī el-Hvārizmī. Mukaddimetüll-Edeb Hvārizm Türkçesi Ile Tercümeli Şuşter Nüshası. Giriş, Dil Özellikleri, Metin, indeks. Ankara. (AKDTYK. TDK Yay. 535.)

Zieme, P. (1977). "Drei neue uigurische Sklavendokumente", Altorientalische Forschungen 5: 145-170.

Zieme, P. (1984). "Zur Verwendung der Brāhmī-Schrift bei den Uiguren (Anhang: Ein uigurischer Neujahrssegen)", Altorientalische Forschungen 11/2: 331-346.

Zieme, P. (2005). Magische Texte des uigurischen Buddhismus. Mit 208 Abbildungen auf 97 Tafeln. Turnhout: Brepols. (BBAW. Akademienvorhaben Turfanforschung. BT. 23.) 
Zieme, P. (2015). Altuigurische Texte der Kirche des Ostens aus Zentralasien. Piscataway, NJ: Gorgias Press. (Georgias Eastern Christian Studies. 41)

Zieme, P. ve G. Kara (1979). Ein uigurisches Totenbuch. Nāropas Lehre in uigurischer Übersetzung von vier tibetischen Traktaten nach der Sammelhandschrift aus Dunhuang, British Museum Or. 8212 (109). Budapest. (BOH. 22) [aynı zamanda Wiesbaden'da yayımlandı (AF. 63.)] 


\section{EXTENDED ABSTRACT}

\section{Introduction}

Considering the historical development of the Turkic language, inscriptions and manuscripts belonging to the periods of the Second Turkic Khanate (632-744), the Uighur Khanate (744-840) and the Uighur Kingdom of Kocho (860-1284), and the inscriptions found in Yenisei, Mountainous Altai and Kyrgyzstan constitute the basic written sources of Old Turkic. Although some scholars wanted to include the first period works written in Karakhanid in Old Turkish, there is two known dialects of Old Turkic, the first of these is Orkhon Turkish and the latter is Old Uighur. The texts of this period contain many terms related to diverse fields, such as religious, social, cultural and military terms. One of them is also the concepts used to name the smell and the concepts of incense and censer. The aim of the paper is to determinate the words in the meanings of smell, incense and censer in Old Turkic texts and to explain these words etymologically. In this study, the words in question determinated in the inscriptions and manuscripts in Orkhon Turkic and Old Uighur are taken as lexical entry; in addition, the texts of other periods of historical Turkish languages are cited for these lexical entries and their forms in the original texts and bilingual dictionaries of Turkic languages are also demonstrated. The lexical materials in question in this paper are examined under two categories: Words and phrases relating to Smell in Old Turkic and Incense and Censer in Old Turkic.

\section{Words and phrases relating to Smell in Old Turkic}

The following words in the shape of noun and verb are determinated among the terms related to smell in Turkic runic inscriptions and Old Uighur texts: burcomes to mean 'to steam; to be fragrant'. The verb bur-is translated into Arabic with the words fāhat, tadawwa'a and irtafa'a in Compendium of Turkic Dialects by Maḥmūd al-Kāshgharī. burı- is translated into Arabic with the phrase fäḥa'lmisk in Kitāb al-'idrāk li-lisān al-'atrāk by 'Abū Ḥayyān al-'Andalusī. kapir < Skt. karpūra 'camphor (either the plant or resinous exudation or fruit)' (MonierWilliams, 1899: 258b). The Chinese equivalent of kapir is attested as 龍腦 long nao in Goldenlight Sūtra, chapter 6 (Ayazlı, 2012: 315b). kin yıpar means 'musk'. In Compendium of Turkic Dialects, kin yıpar renders Arabic nāfica. In Kutadgu Bilig kin yıpar 'misk-bag' is attested as a hendiadys. The word kin is translated into Arabic with the phrase al-misk in Kitāb al-idrāk li-lisān al-'atrāk. kinlig is attested in Bilgä Qagan inscription in the meaning of 'musky'. It can be suggested the form of kin+lig for the expression of the word. kisarlıg < Skt. keśara and Turkic +lıg. Skt. keśara 'pollen' (Edgerton, 1953: 193a). köti- means 'to smell pleasantly, to emit a fragrance' (Erdal, 1991: 483). The Chinese 
equivalents of the verb köti- documented in Old Uighur texts are 芬馥 fenfu，香 xiang and 薰 xun. sası- comes to mean 'to stink'. Old Turkic verb sası- is translated into Arabic with the word natuna in Compendium of Turkic Dialects by Maḥmūd al-Kāshgharī. sasıg means 'stinking'. It appears as sası in Kitāb al'idrāk li-lisān al-'atrāk with Arabic equivalent șınatu'l-bevl. şaruki < Skt. śallakī 'incense' (Monier-Williams, 1899: 1059b). tagar < Skt. tagaraka 'Tabernaemontana coronaria and a fragrant powder prepared from it' (MonierWilliams, 1899: 432a). tütit- comes to mean 'to make (something) smoke' (Clauson, 1972: 452a) and is the Old Uighur equivalent of Chinese 熏 xun. tütitil- is in the meaning of 'to parfume' and it is the Old Uighur equivalent of Chinese 熏 xun. tütnä- comes to mean 'to smoke'. yıd means 'scent, fragrance'. The Chinese equivalents of the word yıd documented in Old Uighur texts are 芳 fang, 臭氣 xiu qi, and 氣 qi. yıdı- is in the meaning of 'to stink' and it is the Old Uighur equivalent of Chinese 香 xiang. The verb $y ı d_{\imath}$ - is translated into Arabic with the words ahamma, antana and natina in Compendium of Turkic Dialects by Maḥmūd al-Kāshgharī. yıdıg means 'smell, odour'. In Old Uighur texts, it has the Chinese equivalents such as 臭穢 and 臭 xiu. The word yıdıg is translated into Arabic with the word muntin in Compendium of Turkic Dialects. yıdla- is in the meaning of 'to smell' and its Chinese equivalent documented in Old Uighur texts is 聞 wen. yıdlıg comes to mean 'having a smell' and its Chinese equivalent documented in Old Uighur texts is 香 xiang.

\section{Incense and Censer in Old Turkic}

The following words are determinated among the terms related to incense and censer in Turkic runic inscriptions and Old Uighur texts: kokılık means 'incense'.

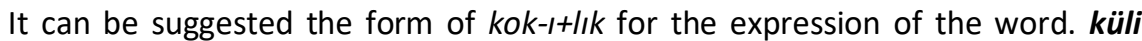
comes to mean 'censer' and Kara and Zieme compare this word with Mongolian külis (1976: 39). küži < Skt. kuśa 'the sacred grass used at certain religious ceremonies' (Monier-Williams, 1899: 297a). lug 'censer' < Chinese 鑪 lu 'a stove; a réchaud; a censer; a brazier' (G. 7416). lukura means 'incense' and its Skt. equivalent is guggula (DDB). tupi(m?) < Skt. dhūpa incense, perfume, aromatic vapour or smoke proceeding from gum or resin' (Monier-Williams, 1899: 517c). tütsüg means 'incense' and its Chinese equivalents documented in Old Uighur texts are香xiang and 香爐 xianglu. tütsüglük comes to mean 'censer' and the form of the word is explained as tüt-üz-üg+lük. The Chinese equivalent of the Old Turkic word is 香爐 xianglu. yıpar is attested in Old Turkic 
texts as yıd yıpar 'incense' in the form of reduplication. Its Chinese equivalents documented in Old Uighur texts are 香 xiang.

\section{Conclusion}

Thematic analysis of the vocabulary of Old Turkic is important for determining the boundaries of the cultural environment in which the Turks live. The comparative analysis of this will also shed light on the changes in meaning in historical and modern Turkish. In order to better understand the vocabulary of Old Turkic texts, it is necessary to examine these texts in their source languages. 